Review Article

\title{
Autoantibodies as Diagnostic Markers and Mediator of Joint Inflammation in Arthritis
}

\author{
Qinghua Fang, Jiaxin Ou, and Kutty Selva Nandakumar $\mathbb{D}$ \\ School of Pharmaceutical Sciences, Southern Medical University, Guangzhou, China \\ Correspondence should be addressed to Kutty Selva Nandakumar; nandakumar@smu.edu.cn
}

Received 22 July 2019; Accepted 14 September 2019; Published 27 October 2019

Academic Editor: Antonella Fioravanti

Copyright (C) 2019 Qinghua Fang et al. This is an open access article distributed under the Creative Commons Attribution License, which permits unrestricted use, distribution, and reproduction in any medium, provided the original work is properly cited.

\begin{abstract}
Rheumatoid arthritis is a systemic, polygenic, and multifactorial syndrome characterized by erosive polyarthritis, damage to joint architecture, and presence of autoantibodies against several self-structures in the serum and synovial fluid. These autoantibodies (anticitrullinated protein/peptide antibodies (ACPAs), rheumatoid factors (RF), anticollagen type II antibodies, antiglucose-6 phosphate isomerase antibodies, anticarbamylated protein antibodies, and antiacetylated protein antibodies) have different characteristics, diagnostic/prognostic value, and pathological significance in RA patients. Some of these antibodies are present in the patients' serum several years before the onset of clinical disease. Various genetic and environmental factors are associated with autoantibody production against different autoantigenic targets. Both the activating and inhibitory Fc $\gamma$ Rs and the activation of different complement cascades contribute to the downstream effector functions in the antibody-mediated disease pathology. Interplay between several molecules (cytokines, chemokines, proteases, and inflammatory mediators) culminates in causing damage to the articular cartilage and bones. In addition, autoantibodies are proven to be useful disease markers for RA, and different diagnostic tools are being developed for early diagnosis of the clinical disease. Recently, a direct link was proposed between the presence of autoantibodies and bone erosion as well as in the induction of pain. In this review, the diagnostic value of autoantibodies, their synthesis and function as a mediator of joint inflammation, and the significance of IgG-Fc glycosylation are discussed.
\end{abstract}

\section{Introduction}

Rheumatoid arthritis (RA) is one of the most common autoimmune diseases, which affects approximately $1 \%$ of the world population, and is characterized by autoantibody production, synovial inflammation, cartilage destruction, and bone erosion [1]. RA occurs when the immune system mistakenly attacks our own body's tissues, causing systemic inflammation damaging not only the articular joints but also a wide variety of other organs including the skin, eyes, lungs, heart, and blood vessels. Many serological studies have shown that a great diversity of well-characterized autoantigens exists in RA patients, for example, citrullinated proteins and peptides, including fibrin; components of articular cartilage (collagen type II, CII); circulating serum proteins including antibodies and acute phase proteins; nuclear components; enzymes (calpain inhibitor protein); and other target antigens [2]. In RA, an increased number of autoantibodies directed against these self-antigens such as rheumatoid factors (RF) and anticitrullinated protein antibody (ACPA) are commonly prevalent.

The inflammation in RA causes joint damage at the early stages itself leading to bone erosion and functional disability. RA patients often have immune system dysfunction and are associated with extra-articular manifestations involving several organs [3]. With the continuous development of medical standards, the progress of RA patients can be alleviated by regular treatment but it cannot be completely cured. Therefore, exploring the pathogenesis of RA is very important for developing precise treatments and new drug targets. Although being a considerable health problem, information about the disease pathways and etiology is far from clear [4] because of the heterogeneity of the disease phenotype. A large number of studies have found that abnormally increased immune cells ( $\mathrm{T}$ cells, B cells, macrophages, and neutrophils) and immune molecules (cytokines, autoantibodies, and heat 
shock proteins) are present in the synovial tissue and fluid of RA patients, which suggest that the release or activation of them may be involved in the initiation and perpetuation of RA. Therefore, extensive and in-depth understanding of these factors and their interactions in the development of RA is of great significance for its prevention and treatment.

In the 1940s, presence of RF in the serum of RA patients was identified and consequently used as the "gold standard" for the diagnosis [5]. Early diagnosis and treatment can often delay and prevent joint deformities, improving the quality and duration of life for the patients, so it is a prerequisite to identify the patients as early as possible. However, if RA is diagnosed according to the current diagnostic criteria of the American College of Rheumatology (ACR), it is usually not early. The discovery of new specific autoantibodies to improve the early diagnosis rate has become a hot topic in current research. More than ten autoantibodies related to RA were identified, which have greatly helped to develop new early diagnosis and prognosis methods. In recent years, the identification of anticitrullinated protein antibodies as a new diagnostic marker for RA is a new milestone in this field.

Detection of autoantibodies is commonly used to confirm clinical diagnosis or to help define a subset of patients in the diagnostic category [2]. In this review, how specific autoantibody responses change and evolve over time to become more pathogenic, interactions between different autoantibody types, their synthesis, and the role of Fc glycosylation will be discussed. The implications of these findings for the clinical practice are briefly discussed.

\section{Autoantibodies in RA}

It has been recognized for some time now that in the natural history of RA, there is a phase for developing autoimmunity that precedes the onset of clinical symptoms in a large proportion of patients. The most prominent players in this preclinical phase are the autoantibodies, and although no definitive causal link with the development of arthritis has been established, autoantibodies have been shown to induce arthritis in different mouse models [9-11].

At present, autoantibodies related to RA include ACPA, antikeratin antibodies (AKA), antiperinuclear factor (APF), antifibronectin antibody (AFA), antimutated citrullinated vimentin (anti-MCV) antibody, anti-Sa antibody, RF, antiglucose-6 phosphate isomerase (anti-GPI) antibody, anticarbamylated protein (anti-CarP) antibody, antiacetylated protein antibody, antinuclear antibody (ANA), antiheterogeneous nuclear ribonucleoprotein (anti-hnRNP/RA33) antibody, anti-Bip antibody and anticalcitostatin antibody (ACAST), and anti-CII antibody $[12,13]$. Presence of these antibodies in RA is of great significance for early diagnosis and treatment. To prevent irreversible joint damage, early diagnosis and treatment initiation within the first three months of disease onset is essential [14]. Apart from diagnostic value, autoantibodies such as ACPA, RF, and other antimodified protein antibodies are considered as important risk factors for the development of RA and probably play an important role in its pathogenesis.
While the presence of autoantibodies is an important risk factor for future RA and part of the ACR/EULAR RA classification criteria, it does not always lead to the development of disease [15]. This may be explained by the heterogeneous character of the various autoantibody responses present in the individuals being at risk for RA development with different intrinsic properties such as affinity, specificity, isotype composition, and glycosylation. These properties translate into different capabilities for modulating inflammation. Furthermore, autoantibody responses can evolve their pathogenic properties in the period leading up to and during the clinical manifestations of autoimmunity.

\section{ACPA}

APF [16] was confirmed to be a specific antibody to RA in 1964 and found to be present early in the disease. Since then, AKA [17], AFA [18], and anti-Sa antibody [19] were identified as highly specific markers for the diagnosis of RA. All these antibody targets are chemically related, their epitopes having citrullinated structures resulting from the posttranslational modification of arginine, and hence are called ACPA, which are specifically present in RA patients [20]. The enzyme peptidyl arginine deiminase (PAD) catalyzes the modification of arginine residue of a protein into a citrulline residue by an enzymatic reaction called citrullination (Figure 1(a)). The citrullinated proteins are often found in the joints of RA patients but are not specific for the disease. In general, the citrullination of the protein may alter its tertiary structure, interaction with other molecules, cleavage regions, and its solubility to enhance its immunogenicity, which could stimulate the immune response to produce corresponding antibodies [21, 22]. It has been found that a large number of abnormally proliferating macrophages and lymphocytes infiltrate into the synovial tissue of RA patients. PAD enzymes, especially PADI4, are activated in these cells, leading to protein citrullination in the synovial membrane, which in turn stimulates B cells to produce large amounts of ACPA, resulting in ACPA immune complexes (IC). The interaction and deposition of IC can induce the production of a variety of cytokines, causing chronic persistent inflammation of the synovium [23]. Synovial tissue protein citrullination has been shown to play an important role in the disruption of immune tolerance mechanisms in RA.

Under normal circumstances, citrullinated proteins degrade regularly and do not trigger any related humoral immune response, so the presence of citrulline proteins itself does not necessarily lead to chronic inflammation [24]. Also, it is a process that exists in a wide range of inflammatory tissues, indicating that it is an inflammatory phenomenon that should usually be tolerated by the immune system. Citrullination seems to be related to many of these accessory physiological processes, such as the pathway of cell death, in which intracellular calcium concentrations rise to higher levels than physiological conditions. Therefore, PAD is activated during apoptosis, autophagy, and NET formation, and it is well known that these processes are related to autoimmunity. Hence, citrullination may be considered as an 


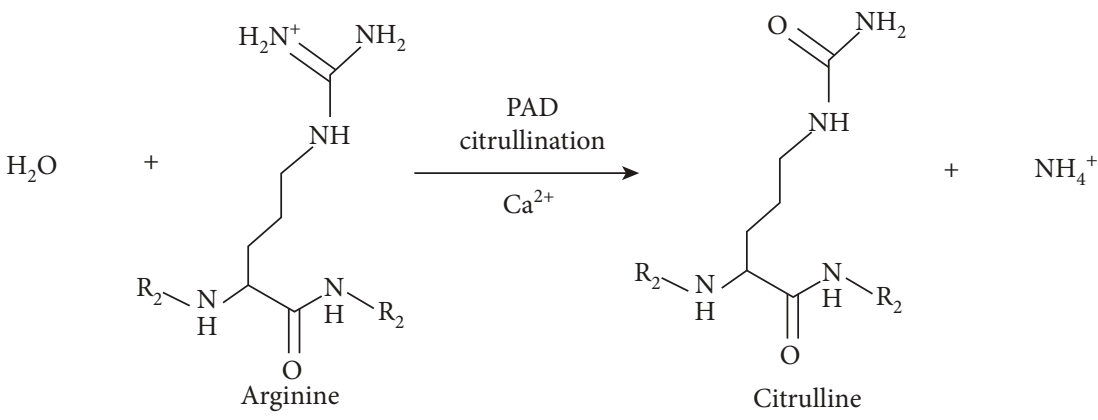

(a) Citrullination

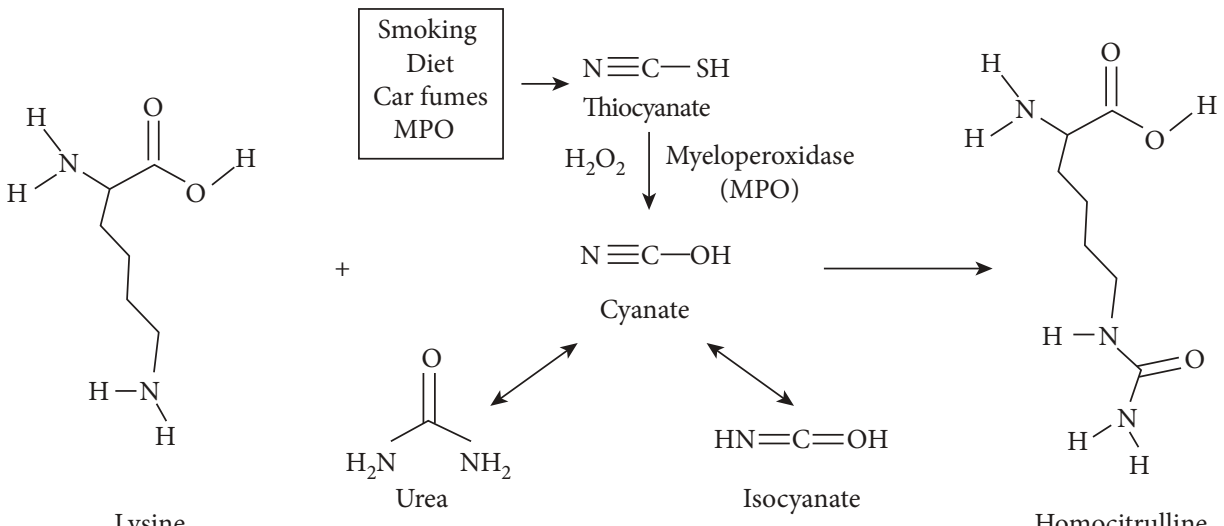

(b) Carbamylation

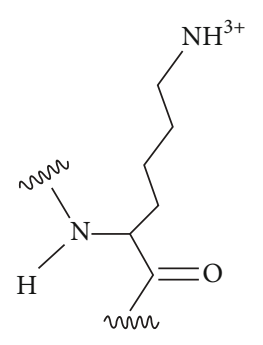

Lysine

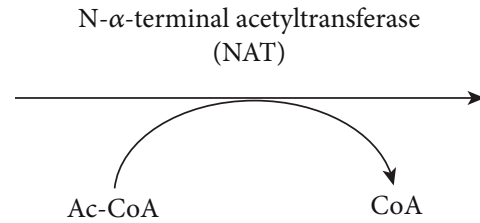

Ac-CoA
CoA

Homocitrulline 
vimentin) that are highly expressed and citrullinated in the inflamed synovia, and nuclear proteins (histones) that become accessible to the immune system under inflammatory conditions in the neutrophil extracellular traps (NET). Thus, several citrullinated proteins have been described as targets of ACPA: filaggrin [26], vimentin [27, 28], $\alpha$-enolase [29], and other proteins but more particularly the $\alpha$ - and $\beta$-chains of fibrin [30]. Citrullinated fibrinogen, CII, and vimentin, which are known as natural antigens and components of immune complexes, are expressed abundantly in the inflammatory tissues of RA patients and may play important roles in the pathological process of RA.

There is considerable variability of the estimated prevalence of autoantibodies in RA among various studies conducted so far (Tables 1 and 2). First, a lower prevalence of RA was reported in rural compared to the urban regions where it appears to be close to that of Caucasian populations, suggesting an environmental influence related to western lifestyle and/or industrialization [31, 32]. Indeed, in Caucasian cohorts, besides environmental factors, several genetic factors have been identified that predispose to the disease, especially the major susceptibility loci being the HLA-DRB1 alleles [33]. These alleles code for proteins that contain similar amino acid sequences (QKRAA, QRRAA, or RRRAA), also known as "shared epitope" (SE), and are present in 60-80\% of Caucasian RA patients [34]. In Black African patients, the frequency of the SE alleles was also found to be higher in RA patients than in controls, for example, $40 \%$ vs. $10 \%$, in a cohort from South Africa and $30 \%$ vs. $10 \%$ in a Cameroonian cohort, but it was always in lower frequency than the Caucasian patients $(70 \%$ vs. 30\%, for RA and controls, respectively) [35]. Interestingly, in Caucasian patients, the SE alleles are predominantly associated with ACPA-positive RA. Tables 1 and 2 show that patients tested in different countries have varied responses to different antigens, which might explain the differences observed in the incidence of RA; however, citrullinated peptide is not a natural antigen [36]. Therefore, identifying the natural antigen targeted by anti-CCP in vivo is of great significance for designing the early diagnosis tests for RA.

ACPAs can induce damage when activating classical and alternative complement pathways. It is also capable of triggering immune cell responses via $\mathrm{Fc}$ receptors $(\mathrm{Fc} \gamma \mathrm{Rs})$. In this context, immune complexes containing ACPA and citrullinated fibrinogen have been shown to induce TNF- $\alpha$ secretion on macrophages via binding to $\mathrm{F} c \gamma \mathrm{Rs}$ [4]. ACPAs can also bind osteoclast progenitor cells and directly promote them to differentiate into bone-resorbing osteoclasts. Interestingly, it was observed that bone loss begins even before the onset of clinical disease in ACPA-positive individuals, which suggests that these antibodies might play an independent role in initiating the bone damage [37]. Another mechanism for the ACPA-mediated proinflammatory effect may be through the formation of NET. Neutrophils release NETs containing chromatin associated with granules, which are not only capable of killing extracellular microorganisms but can also act as the source of autoantigens [38]. The role of NETs in producing citrullinated proteins is well recognized and was reported to be essential to generate ACPA [39]. In the form of immune com- plexes, ACPAs can also upregulate the production of proinflammatory cytokines. For example, combination of IgM-RF and ACPA promotes the production of proinflammatory cytokines in vitro [40].

\section{Rheumatoid Factor}

RF has been widely used in the diagnosis of RA since its discovery in 1940 as an antibody directed against serum gamma-globulin, which promoted the agglutination of sheep red blood cells sensitized by subagglutinating doses of rabbit antibodies [41]. RF is an autoantibody reacting against the Fc portion of IgG antibodies, produced locally by B cells present in the lymphoid follicles [42] and detectable in the serum of about $70 \%$ of patients with established RA but less frequently in early RA.

IgM-RF is the earliest discovered RA-related antibody and may be present many years before the onset of clinical disease; thus, its presence may also indicate an increased risk of disease development [43]. Current studies have shown that in addition to IgM-RF, multiple subtypes of RF can be detected in the serum of RA patients by ELISA, such as IgG, IgA, IgE, and IgD, which may predate disease onset by years [41]. Currently, IgM-RF is listed as the only serological indicator in the diagnostic classification of RA and is one of the most widely used biomarkers [44]. The RF-positive rate in RA patients is about $60 \%$ to $80 \%$, but the rate is lower (50-60\%) during early stages [45]. However, there is also a certain positive rate in patients with other systemic autoimmune diseases such as Sjogren's syndrome, mixed cryoglobulinemia, systemic lupus erythematosus (SLE), mixed connective tissue disease (MCTD), and primary biliary cirrhosis and in infectious diseases like chronic tuberculosis, hepatitis C, Epstein-Barr virus infection, cytomegalovirus infection, and subacute bacterial endocarditis [41, 46, 47]. Even in healthy people, RF levels increase with age, and positive reactions can be seen in $5 \%$ of young people and up to $25 \%$ in the elderly [48]. High titers of RF, anti-CCP antibodies, or both are considered as serological hallmarks of RA [49]. Therefore, specificity of IgM-RF alone for RA diagnosis is considered to be insufficient. Similarly, detection of RF does not generally help in monitoring the disease, although it may help with the use of certain biologics, such as etanercept and infliximab, when levels of RF may decrease along with the clinical disease activity $[50,51]$.

Combining different isotypes is more specific than a single antibody. IgM, IgA, and IgG-RF are present in up to $52 \%$ of RA patients but also in fewer than $5 \%$ of patients with other rheumatic diseases. A number of studies have shown that the positive rate of IgG-RF in RA patients is $41.5 \%$ to $66 \%$ [52]. Moreover, IgG-RF has a higher specificity (91\%) in the diagnosis of RA and correlates highly with the joint damage [53, 54]. Therefore, the combined detection of IgG-RF and other RA-related antibodies is of great significance for the diagnosis of RA. The combined occurrence of IgM- and IgA-RF has high diagnostic specificity for RA, but the presence of $\operatorname{IgA}$ and IgG-RF isotypes in the absence of IgM-RF is less specific, since they are also prevalent in patients with diverse rheumatic diseases [45]. The 


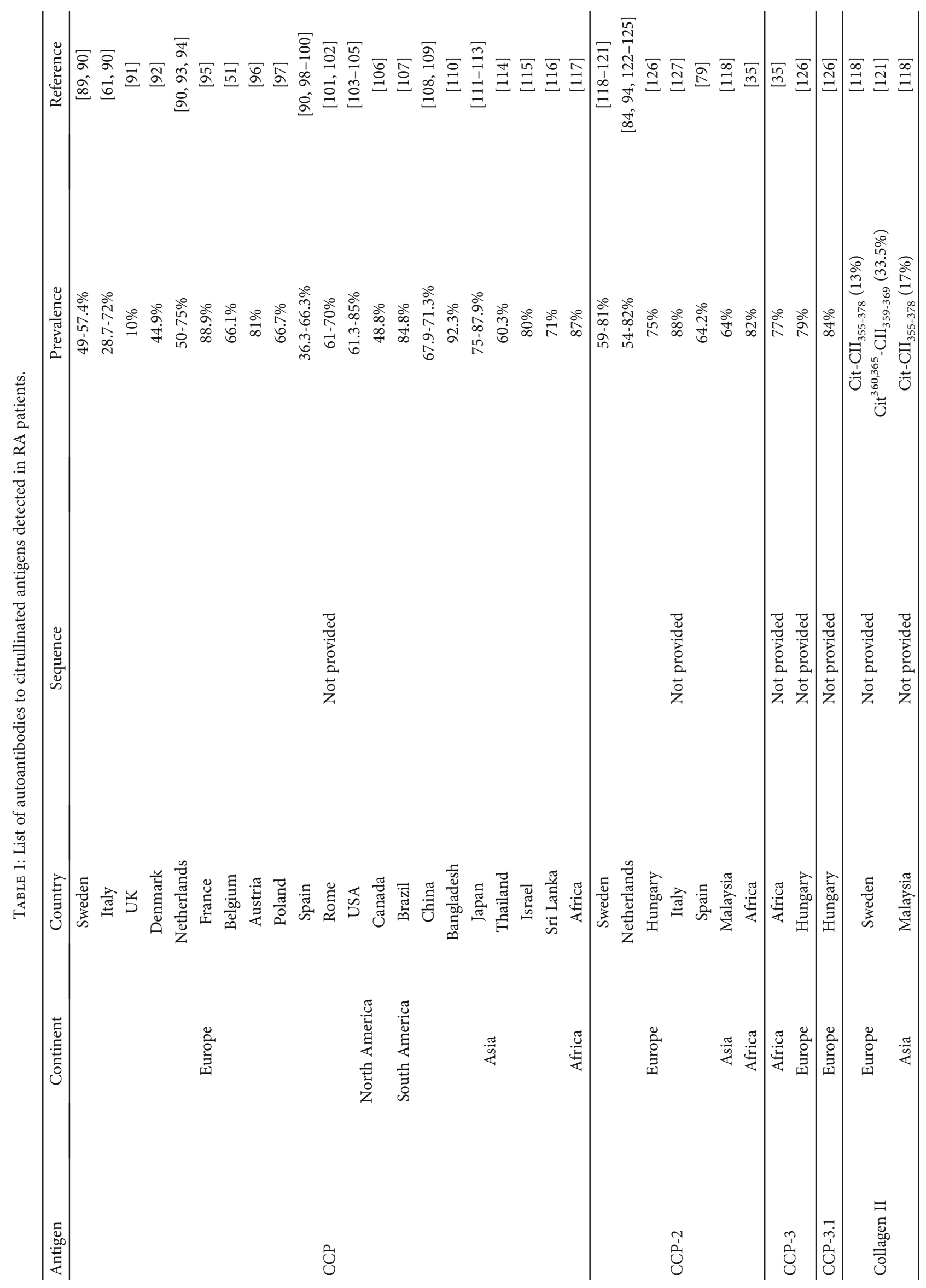




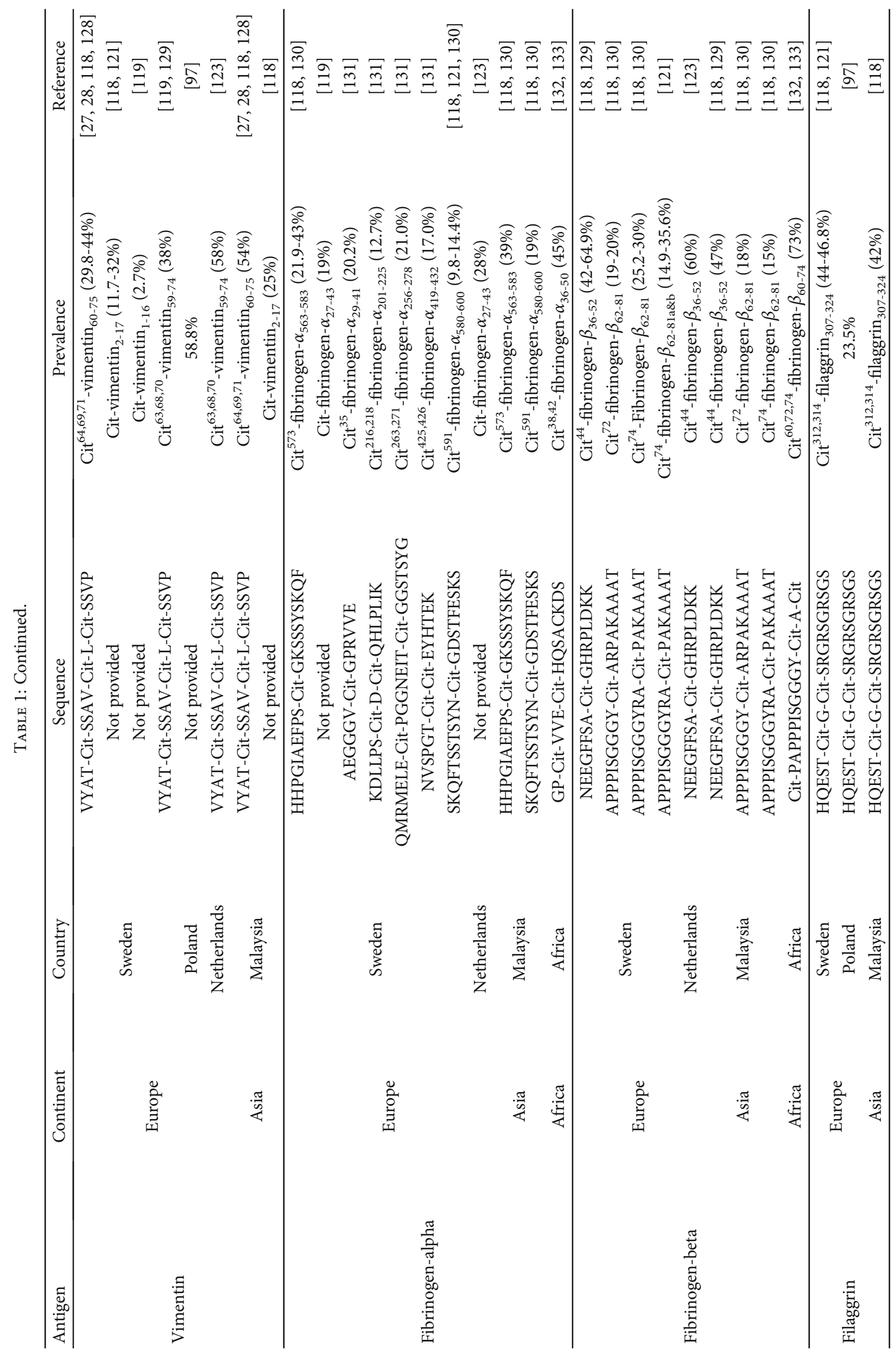




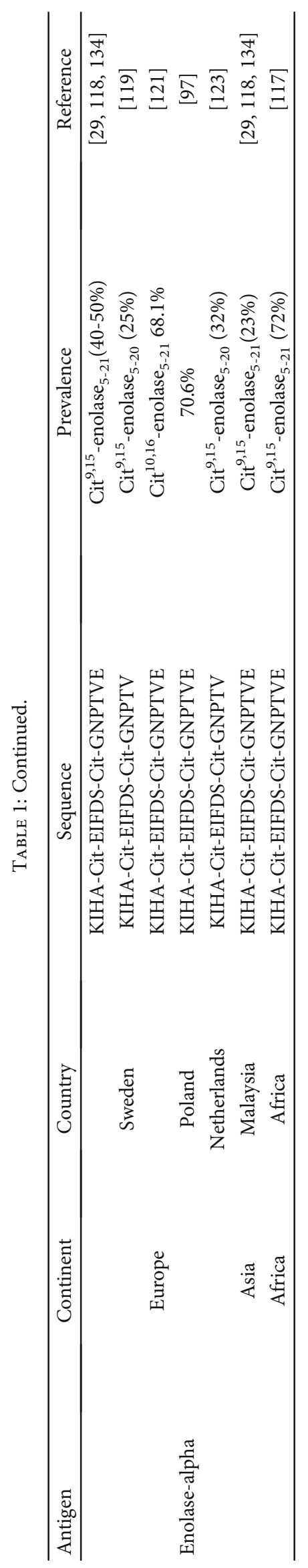


TABLE 2: List of autoantibodies to unmodified antigens detected in RA patients.

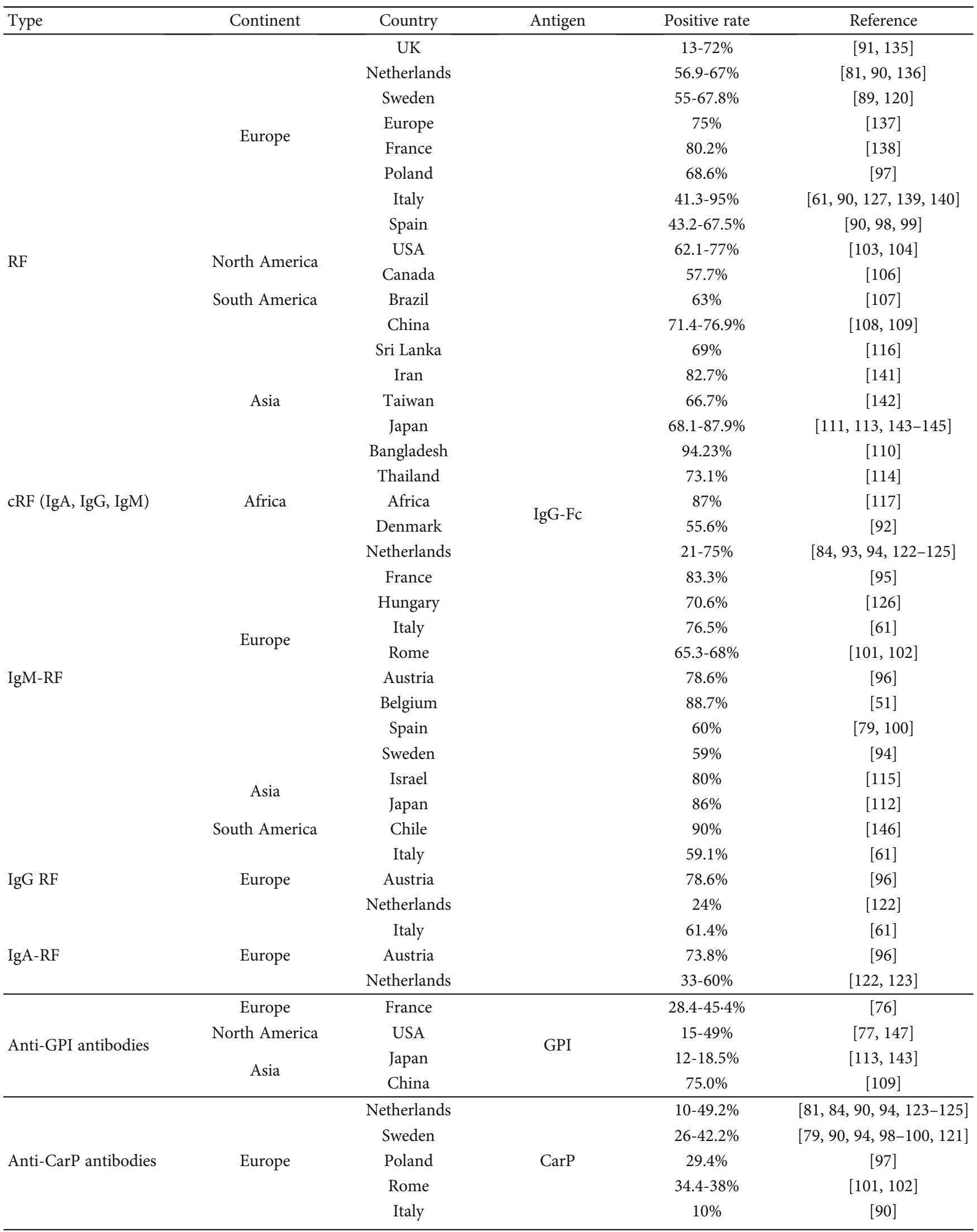


TABLe 2: Continued.

\begin{tabular}{|c|c|c|c|c|c|}
\hline Type & Continent & Country & Antigen & Positive rate & Reference \\
\hline & \multirow{2}{*}{ North America } & USA & & $47 \%$ & {$[90]$} \\
\hline & & Canada & & $38.2 \%$ & {$[148]$} \\
\hline & Asia & India & & $41.5 \%$ & {$[148]$} \\
\hline \multirow{2}{*}{ Antinuclear antibody } & \multirow{2}{*}{ Europe } & Denmark & \multirow{2}{*}{ Nuclear antigens } & $19.4 \%$ & {$[92]$} \\
\hline & & France & & $44.4 \%$ & [95] \\
\hline Antikeratin antibodies & Asia & China & Keratin & $48.2 \%$ & [109] \\
\hline \multirow{2}{*}{ Anti-hnRNP/RA33 } & Europe & Poland & \multirow{2}{*}{ hnRNP/RA33 } & $37.3 \%$ & [97] \\
\hline & Asia & China & & $7.3-44.7 \%$ & [149] \\
\hline
\end{tabular}

physiological role of RF under normal conditions includes promoting the stability of IgG bound to solid surfaces such as bacterial cell walls, enhancing immune complex clearance by increasing its stability and size, helping B cell uptake of immune complexes, thereby efficiently presenting antigens to $\mathrm{T}$ cells, and facilitating complement fixation by binding to IgG containing immune complexes [45].

The RF in RA patients is relatively of high affinity in nature, which is different from the poly-reactive and low affinity RF present in the healthy individuals [55]. Studies have shown that RF is a pathogenic autoantibody that plays a key role in the pathophysiology of RA [56]. In normal conditions, transient production of low-affinity IgM-RF is regularly induced by immune complexes and polyclonal $\mathrm{B}$ cell activators, such as bacterial lipopolysaccharide and Epstein-Barr virus [57]. The main role proposed for RF in RA is to form immune complexes, fix complement, and release chemokines, such as $\mathrm{C} 5 \mathrm{a}$, thus recruiting inflammatory cells (neutrophils) into the joints. Then, the activated inflammatory cells phagocytize the immune complexes and release proteolytic enzymes, causing joint tissue destruction. In addition, RF could also be involved in the retention of antigens within the joint. In this way, formation of immune complexes at the sites of synovial inflammation will be induced, and complement and leukocyte infiltrations will be ensured [58]. RF-specific B cells migrate into the synovium of RA patients, expressing multiple antigens to $\mathrm{T}$ cells, which may contribute to the continuation of local inflammatory responses and the expansion of synovial RF products. Therefore, RF may prolong the survival of B cells and thus maintain their own production.

Unlike lgM-RF, aggregated IgA-RF activates the complement through the alternative pathway to participate in the pathological processes. Polymerization of IgA-RF and IgG into an immune complex can stimulate neutrophil release of elastase, cathepsin, lysozyme, and myeloperoxidase to participate in the bone destruction [59]. Nonpolymeric IgA-RF can also regulate the phagocytosis of monocytes. It was observed that IgA-RF can selectively activate macrophages to produce prostaglandins, IL- 1 , TNF- $\alpha$, and other cytokines causing degradation of the bone matrix and damage to the cartilage. Interestingly, memory $B$ cells expressing the IgA-RF receptor FcRL4 were also found in the joints of RA patients, which via RANKL expression can contribute to joint destruction [60].
RF plays a pivotal role in the differential diagnosis and prognosis of RA patients [57]. It has been shown that RF is useful in predicting the development of RA, as the detection of IgM-RF can be used as a marker of inflammatory activity [61]. The preclinical appearance of RF isotypes in the serum follows a specific sequential evolution: first IgM, then IgA, and finally IgG-RF [62]. These three autoantibodies have different meanings in clinical diagnosis and should be treated differently: Elevated levels of IgM- or IgA-RF alone suggest the possibility of infection. If the IgM- or IgA-RF titer is progressive even after anti-infective treatment, the possibility for positivity for RA is high. On the other hand, elevated IgG$\mathrm{RF}$ alone suggests a higher probability of RA, and if the antibody titer is significantly increased, it may be associated with vasculitis. If IgM- and IgA-RF increase simultaneously, then the possibility for RA is high. If all the RF isotypes (IgM, IgG, and IgA) increase simultaneously, RA can be diagnosed positively but it still needs to be differentiated from other diffuse connective tissue diseases.

High titers of RF have been associated with worse prognosis, more aggressive articular disease, increased disease activity, reduced rates of remission, higher prevalence of extra-articular manifestations, and increased morbidity and mortality, especially when present in combination with ACPA $[62,63]$. In addition, when the patient's serum has high levels of IgM- and IgA-RF, the disease progresses rapidly suggesting that bone erosion and bone destruction are prone to occur and the continuous increase of IgM- and IgG-RF in the serum can lead to poor prognosis [64]. However, studies showing the clinical usefulness of RF in monitoring disease activity and treatment response are limited. We still need more indicators to judge and understand various conditions or subtypes of RA. As a sensitive marker of acute phase proteins and inflammatory responses in vivo, C-reactive protein (CRP) can effectively compensate for the negative results of partial RF screening in the diagnosis of autoimmune diseases, which could effectively avoid the occurrence of misdiagnosis and missed diagnosis $[65,66]$.

\section{Antiglucose-6 Phosphate Isomerase (Anti-GPI) Antibodies}

GPI is an important enzyme in glycolysis and gluconeogenesis in the body and can be secreted outside the cell as a cytokine or growth factor. However, GPI is also an autoantigen in 
RA. In a T cell receptor transgenic (KBN) mouse model, continuous production of GPI-specific antibodies was detected [67]. Transfer of these antibodies to healthy mice induced arthritis [68]. Complement components [69], especially the alternative pathway of activation [70], cells bearing Fc $\gamma$ Rs [71], and various inflammatory cytokines, play an important role in the disease pathogenesis. Immunization of mice with recombinant GPI [72] or GPI peptides [73, 74] can also induce arthritis in naive mice. In 2001, Schubert first reported that anti-GPI antibodies were associated with RA [75]. Subsequently, Jouen et al. reported the positive rate of anti-GPI antibody in the serum of RA patients as about $45.4 \%$, but the specificity was only $75.0 \%$ and the appearance of antibodies was not correlated to the prognosis of RA patients [76]. Moreover, anti-GPI antibodies were found to be not specific for RA [77].

\section{Anticarbamylated Protein Antibodies}

Anticarbamylated protein (anti-CarP) antibodies are a new type of autoantibodies described in RA recently. Similar to citrullination, carbamylation is a kind of posttranslational modification of proteins, which provides a source of new epitopes that can be recognized as non-selfantigens [78]. Carbamylation is a chemical reaction mediated by cyanide in which a lysine is converted into a homocitrulline (Figure 1(b)). Certain conditions, for example, renal disease, smoking, and inflammation, can increase cyanide levels and thus carbamylation. Presence of these modified sequences of amino acids may provoke specific autoantibody production in RA. Antibodies in the serum of RA patients can discriminate citrullinated and carbamylated antigens. Therefore, this antibody system is independent of ACPA [57]. However, cross-reactivity between ACPA and antiCarP antibodies is observed. Nevertheless, at least a subpopulation of anti-CarP seems to be independent of ACPA and associated with erosive disease [79].

In an animal model, it was shown that carbamylated proteins can trigger primary immune responses inducing chemotaxis, $\mathrm{T}$ cell activation, antibody synthesis, and production of IFN- $\gamma$, IL-10, and IL-17. The activation of T cells and a strong antibody response enabled the recognition of carbamylated and citrullinated peptides within the joints, which further contributed to the development of erosive arthritis [79]. Carbamylated and citrullinated peptides complement each other in the generation of the autoimmune responses. The immune-activating effects of carbamylation enhance the arthritogenic properties of citrullinated peptides, thus providing a novel mechanism for the pathogenesis of autoimmune arthritis [80]. Verheul and colleagues have identified carbamylated alpha 1 antitrypsin (A1AT) as an antigenic target of anti-CarP antibodies in RA patients [81].

Similar to the citrullination, increased carbamylation alone does not seem to be sufficient to break the tolerance to induce autoimmunity. Only $12 \%$ of patients with renal disease harbor anti-CarP antibodies compared to approximately $44 \%$ of RA patients [82]. Anti-CarP antibodies consist of $45 \%$ IgG and $43 \%$ IgA isotypes. Notably, anti-CarP antibodies may occur in $16 \%$ to $30 \%$ of ACPA-negative patients
(16\% IgG and 30\% IgA isotypes) [83]. Moreover, anti-CarP antibody was reported to be associated with radiographic progression in patients negative for RF and ACPA. However, diagnostic classification of RA patients did not improve by adding anti-CarP testing, as RF and ACPA are already good predictors for the disease [83]. Overall, the sensitivity of anti-CarP is lower than ACPA; however, the simultaneous assessment of anti-CarP and ACPA may be very beneficial to identify RA patients [84].

\section{Antiacetylated Protein Antibodies}

The latest addition to antimodified protein antibodies (AMPAs) in RA patients is antiacetylated protein antibodies present in approximately $40 \%$ of RA patients, mainly in the ACPA-positive group. Similar to citrullination, acetylation may be involved in the pathogenesis of RA by triggering the production of autoantibodies and/or by producing antibody response targets in rheumatoid joints [85]. Acetylated lysine resembles homocitrulline, but the side chain terminal amine is replaced by a methyl moiety in acetylated lysine (Figure 1(c)). Acetylation is a reversible enzymatic process in which acetyl groups are added to free amines of lysine residues by lysine acetyltransferases (KAT) [86]. Protein lysine acetylation is a key posttranslational modification in cellular regulation, especially in histones and nuclear transcription regulators. Recently, mice carrying a HDAC1 deletion in their $\mathrm{CD}^{+} \mathrm{T}$ cells are reported to be protected from autoimmune disease [87]. Moreover, acetylation of cytoplasmic proteins regulates metabolic pathways and enzymatic functions.

IgG and IgA antibodies against acetylated vimentin peptides were detected in 35\% of patients with early arthritis. However, data showed that antiacetylated vimentin antibodies are relatively poor for predicting the development of anti-ACPA-negative RA. Their presence and frequency in established RA and their role in predicting disease severity and other clinically relevant outcomes in RA patients remain to be established. Detection rates in sero-negative RA patients were comparable to patients with resolving arthritis rendering it unlikely that these antibodies will be a new biomarker helpful for diagnosing RA [85]. However, antiacetylated protein antibodies might provide useful new insights into pathophysiology, especially in the era in which the microbiome seems to become increasingly important. Acetylation is an enzymatic process, which can be affected by bacteria, although the underlying mechanism is unclear. Therefore, antiacetylated antibodies could provide a possible new link between microbiome dysbiosis and the development of autoimmunity in RA [88].

The diagnosis of RA usually depends on imaging examination, clinical characteristics, and results of autoantibody tests. However, the common clinical manifestations are not specific to RA, and the diagnostic values of autoantibodies are not considered as satisfactory $[41,150]$. Therefore, it is necessary to establish alternate methods or discover new antibodies to further improve precise diagnosis. Fibrinogen is a precursor form of fibrin which deposits abundantly in the joints of RA patients. After the discovery of citrullinated 


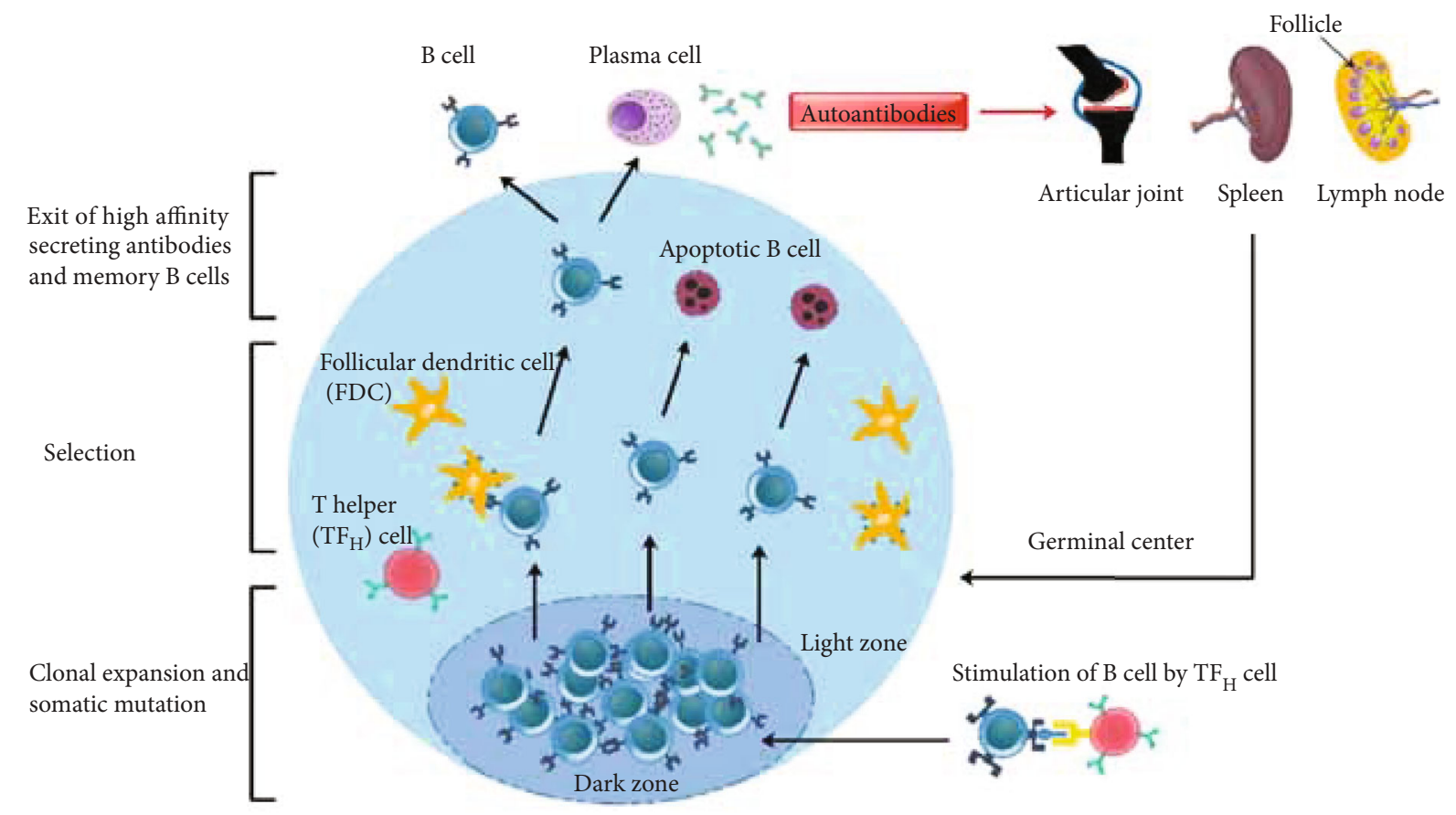

Figure 2: Germinal centers refer to sites within secondary lymphoid organs, lymph nodes, and the spleen where mature B cells proliferate, differentiate, and mutate their antibody genes by highly mutating somatic B cells to generate higher affinity (through somatic hypermutation) and class-switched antibodies. These cells developed dynamically after T-dependent antigen-activated follicular B cells. Formation of ectopic lymphoid aggregates with GC-like structures in the inflammatory tissues of RA patients is considered to contribute to the pathogenesis of arthritis.

fibrin in RA patients, research regarding the association between anticitrullinated fibrinogen (ACF) antibody and RA has gradually increased. One meta-analysis reported moderate diagnostic value for ACF in RA with a high specificity but limited sensitivity [151]. The sensitivity and specificity of ACF were similar to anti-CCP antibodies, so it may possess the similar diagnostic value in RA patients as anti-CCP antibodies [152]. However, the sensitivity of ACF is higher than that of IgM-RF and it is also related to the imaging progress of RA [153]. Therefore, ACF may contribute to the diagnosis of RA when combined with other antibodies and also in the clinical manifestations.

\section{Natural and Pathogenic Autoantibodies}

Even in the absence of an external antigen stimulation, natural autoantibodies (NAbs) can be secreted by B1a cells, which can present antigens efficiently, serving housekeeping functions and maintaining the homeostasis of the whole immune system. NAbs are not only limited to protecting the host from exogenous pathogens but can also act as key guard of the immune system by removing autoantigens and scavenging own tissues, such as dead or apoptotic cellular debris [154]. NAbs are mostly antibodies of the IgM isotype (also contain IgG and IgA isotypes) characterized by polyreactivity, with low titer and low-to-moderate antigenbinding affinities [155]. Natural antibodies are germline- or close to germline-encoded variable regions directed against both microbial and altered self-antigens [156]. Interestingly, B1 cells also have an important role in the production of pathogenic autoantibodies in several autoimmune diseases, including RA.

High affinity autoantibodies having various effector functions, which are achieved in the germinal centers (GCs) of the secondary lymphoid organs, are essential for driving the autoimmune diseases. Although B cells can differentiate into short-lived plasma cells outside GCs, plasma cells matured within GCs produce more high affinity antibodies [157]. Follicular dendritic cell (FDC) networks play a pivotal role in maintaining GCs, as GC formation is abrogated in the absence of such FDC networks. Studies using gene-targeted mice have highlighted the nonredundant role of the inducible costimulatory molecule (ICOS), CD40, and lymphotoxin in the initiation and maintenance of GC niches [158]. In GC, follicular $\mathrm{T}$ helper $\left(\mathrm{TF}_{\mathrm{H}}\right)$ cells and $\mathrm{B}$ cells cooperate to mediate Ig class switching, affinity selection, generation of memory B cells, and antibody secreting plasma cells [159] (Figure 2). Various signaling molecules (for example, ICOS, CD40-CD40L, and signaling lymphocyte activation molecule- (SLAM-) associated protein (SAP)) are reported to be involved in $\mathrm{TF}_{\mathrm{H}}$ cell-B cell interactions in the GCs. In the absence of help from $\mathrm{TF}_{\mathrm{H}}$ cells, GC reactions were reported to be disrupted [160]. B cells present in the GC that are stimulated by antigen and $\mathrm{TF}_{\mathrm{H}}$ cells differentiate into memory $\mathrm{B}$ cells and long-lived plasma cells secreting such high affinity antibodies. Many of the autoantibodies show characteristics of GC origin, suggesting defective selection of GC B cells in autoimmune diseases [161]. A specific role for $\mathrm{TF}_{\mathrm{H}}$ cell-B cell interactions in the development of autoimmunity has been identified by studies done with Roquin ${ }^{\text {san/san }}$ mice. 
These mice are homozygous for a knockout in the Roquin (Rc3h1) allele, encoding a member of the RING-type ubiquitin ligase protein family responsible for RNA translation and stability in $\mathrm{CD} 4^{+} \mathrm{T}$ cells [162]. Roquin ${ }^{\mathrm{san} / \mathrm{san}}$ mice show spontaneous GC formation with an increased synthesis of pathogenic autoantibodies, which could be due to a defect in the selection process for autoreactive B cells in the GCs [162].

RA is a chronic inflammatory disease, and autoantibodymediated pathology contributes to joint inflammation and destruction. Production of high affinity autoantibodies in RA suggests presence of these specialized lymphoid structures, GCs, which are usually found within secondary lymphoid organs, such as the spleen and lymph nodes, but have been observed in ectopic locations like inflamed joint tissues as well $[163,164]$. Ectopic GCs were reported to be present in $25-50 \%$ of RA patients. However, it was observed that ectopic GCs might not be the major contributors of autoantibodies during inflammatory responses in RA patients [165]. Hence, contribution of GCs to clinical RA is far from clear. In collagen-induced arthritis (CIA), a classical experimental model of RA, GCs are present in both the limbs and secondary lymphoid tissues [166]. Upon collagen immunization, GCs were formed [167] and found to be indispensable for the development of CIA [168].

Analysis of mutations in genes encoding the immunoglobulinvariable $(\mathrm{IgV})$ region in various autoimmune diseases showed that autoimmune $\mathrm{B}$ cells contain more $\mathrm{IgV}$ mutations than healthy B cells [169]. However, IgV mutations in RA GC B cells are directed only against selected few antigens [170]. Interestingly, studies with a germline-encoded anti-CII IgH replacement mouse strain revealed that self-antigen-specific $B$ cells were neither deleted nor anergized. IgH/L chain sequence data of $B$ cell clones generated from these mice revealed lack of somatic mutations in the autoreactive B cells, but the monoclonal antibodies generated from these mice induced arthritis when combined with another arthritogenic antibody, which suggests pathogenic potential of germlineencoded autoantibodies [171]. It was reported earlier that different genetic regions and their epistatic interactions control autoantibody synthesis $[172,173]$ and CII epitopespecific antibody response is controlled by $\operatorname{IgV}(\mathrm{H})$ gene polymorphisms [174].

Thus, autoantibodies produced either directly or as constituents of immune complexes can trigger inflammation $[175,176]$. Passive transfer of purified IgG antibodies from RA patients in naive [177] or mice deficient in the lowaffinity inhibitory Fc receptor, Fc $\gamma$ RIIB [178], induced arthritis. Arthritis induced by the passive transfer of antibodies by binding to its target antigens involves Fc $\gamma$ R-bearing granulocytes, mainly neutrophils and macrophages, and complement activation but without the help of adaptive immune responses [179]. Apart from the inflammation-dependent mechanisms, antibodies could also be directly pathogenic to the cartilage independent of inflammatory cells and factors [180]. Certain anti-CII monoclonal antibodies impaired cartilage formation [181], inhibited collagen fibrillogenesis [182], and disassembled CII fibrils in the extracellular matrix with or without increased matrix synthesis [181], possibly compromising the integrity of the cartilage matrix. Interestingly, anti-CII mAbs induced pain-like behavior that was observed prior and after the appearance of clinical symptoms of arthritis, with the involvement of spinal glia [183], and the cartilage binding antibodies were shown to induce pain through immune complex-mediated activation of neurons [184].

In RA, ACPA is associated with arthralgia before the onset of inflammation and a more aggressive disease ensues, suggesting potential pathogenic effects of the ACPA response [185]. Binding of ACPAs to osteoclasts released IL-8, leading to bone erosion [186] and also enhanced osteoclast differentiation from monocyte-derived or circulating $\mathrm{CD} 1 \mathrm{c}^{+} \mathrm{DCs}$ by increasing the release of IL-8 [187]. Upon binding to its target antigens, ACPAs also induced joint pain by activating sensory neurons via CXCL1/IL-8, released from $\mathrm{CD} 68^{+}$ osteoclasts in an autoantibody-dependent manner, and blocking the chemokine receptors for CXCL1/2 attenuated ACPA-induced hypersensitivity [188]. Furthermore, ACPAs induced macrophages to secrete TNF- $\alpha$-mediated activation of complement cascades [189] and Fc $\gamma$ RIIa-dependent activation of platelets [190]. High titers of RF are also associated with joint erosion and extra-articular manifestations, leading to poor prognosis [191]. Moreover, synovial mast cells express Fc $\gamma$ RIIA and can be activated by IgG-ACPA and Toll-like receptor (TLR) ligands, and the combined activation of mast cells via these pathways greatly enhances inflammation in the synovial tissue of RA patients [191]. Possible pathophysiological mechanisms involved in RA are depicted in Figure 3, and the autoantibodies occupy a central part in them.

\section{IgG Glycosylation}

Importance of posttranslational protein modifications in the rheumatological diseases has been reviewed earlier [193]. In this context, the role of autoantibody glycosylation in the development of arthritis has been widely reported. Antibodies are composed of $82-96 \%$ of protein and $4-18 \%$ of carbohydrates [194]. In IgG, N-linked glycans are present both at asparagine 297 on the $\mathrm{CH} 2$ part of the $\mathrm{Fc}$ domain and in $10-20 \%$ of the Fab part [195-197]. In the Fc part, N-acetyl glucosamine, mannose residues with extensions of galactose, sialic acid, fucose, and bisecting $\mathrm{N}$-acetyl glucosamine are present asymmetrically in both the constant $\mathrm{CH} 2$ domains, whereas Fab glycosylation is present in the complementarity determining regions of both heavy and light chains and framework regions [198]. IgG glycosylation is associated with inflammation and affects most of the antibody-mediated effector functions $[199,200]$, which are dependent on the activation of $\mathrm{Fc} \gamma \mathrm{Rs}$ and complement, and is regulated by Fc glycans. After binding to Fc $\gamma$ Rs or complement, antibodies induce cellular cytotoxicity and cellular phagocytosis as well as cytokine secretion or complement-dependent cytotoxicity, respectively. Decreased galactosylation and sialylation of serum IgG is associated with RA patients [201-206] and in animal models [207]. In RA patients, levels of IgG galactosylation, bisection, and fucosylation are altered [201, 204, 208-212]. In addition, defective 


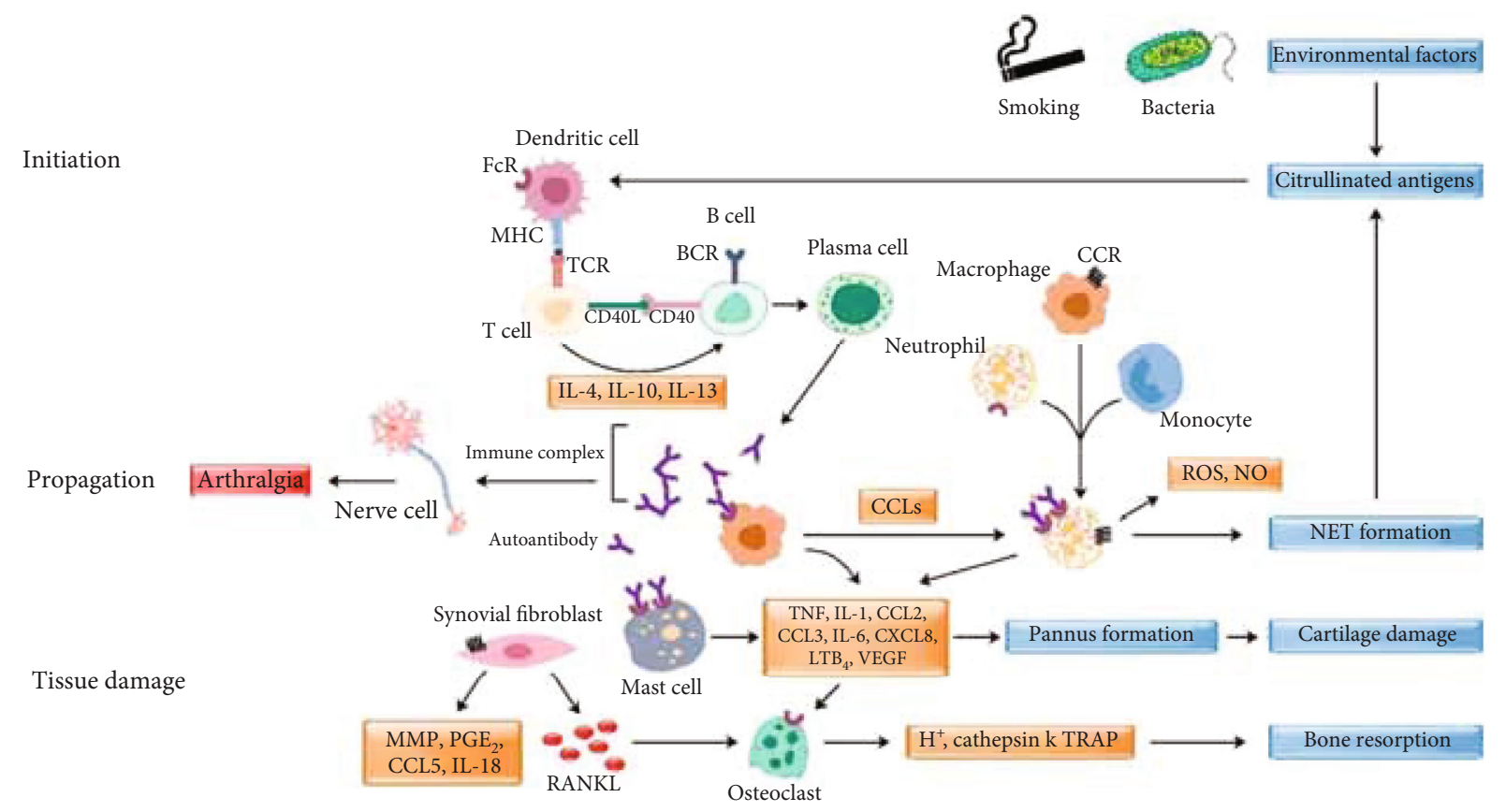

FIGURE 3: Rheumatoid arthritis pathophysiology. This figure describes different immune cells participating in the initiation, propagation, and tissue damage stages of RA. Environmental factors may trigger generation of posttranslationally modified autoantigens (neo-epitopes) that can be presented by professional antigen-presenting cells to $\mathrm{T}$ cells in the context of arthritis-susceptible genetic background. The activation of $\mathrm{T}$ cells leads to increased T-B cell cooperation, secretion of cytokines, differentiation of B cells to plasma cells, and production of autoantibodies. These autoantibodies can induce pain as well as inflammation-dependent and inflammation-independent downstream effector mechanisms leading to activation of cells, secretion of proinflammatory cytokines and proteases, which can destroy the cartilage and bone. During this process, neutrophils form NETs, a source for more citrullinated antigens, completing a vicious cycle that can propagate joint inflammation further. CD40: cluster of differentiation 40/co-stimulatory protein present on antigen-presenting cell (APC); CD40L: cluster of differentiation 41-ligand present on Th cell, bind to CD40 to activate APC; TCR: T cell receptor; BCR: B cell receptor; MHC: major histocompatibility complex/surface receptor, with its ligand-activated TCR; FCR: FC receptor/protein receptor present on immune cells; CCR: c-c-motif receptor/beta chemokine receptor; CCL5: chemokine [c-c-motif] ligand-5/RANTES/its chemotactic for neutrophils; CCL2: chemokine [c-c-motif] ligand-2/MCP1; CCL3: chemokine [c-c-motif] ligand-3/MIP-1; CXCL8: IL-8; LTB: TNF-C/induce inflammatory response; VEGF: vascular endothelial growth factor; pannus: abnormal fibrovascular tissue lies over joint surface; MMP: matrix metalloproteinase; PGE: prostaglandin E; IL-1B: interleukin-1-beta; cathepsin k: enzyme controlling bone remodeling; ROS: reactive oxygen species; NO: nitric oxide; IL-4: interleukin-4; IL-10: interleukin-10; IL-13: interleukin-13; T cell: T lymphocyte; B cell: B lymphocyte; TNF: tumor necrosis factor; IL-1: interleukin-1 [192].

galactosylation in the IgG-Fc glycans was observed in RA patients [204, 213, 214] and arthritic MRL-lpr/lpr mice [215]. It was found that agalactosyl IgG has significantly reduced binding to Clq and to Fc $\gamma$ Rs [216]. Clustered IgG in the synovial cavity facilitates multiple presentation of G0 glycans to mannose-binding protein that can lead to complement activation [210], and the mannose-binding lectin activity and G0 glycans correlate with arthritis onset [217]. Treatment of RA patients also changes the profile of IgG glycosylation $[218,219]$. Similarly, agalactosyl IgG is associated with disease activity in experimental arthritis [220]. In addition, increased Fab glycosylation was also reported from RA patients [221, 222].

In mice, inhibiting sialylation in activated $B$ cells increased joint inflammation, whereas sialylation of antiCII monoclonal antibodies (mAbs) attenuated their pathogenic potential [223]. Similarly, pathogenic properties of KBN sera were altered when sialic acids attached to IgG-Fc were cleaved using sialidase or after injection of sialic acid enriched IgG-Fc fragments [224]. Significant changes in IgG-Fc galactosylation and fucosylation in ACPA prior to the onset of RA were observed [205], which is also dependent on IgG subclass [225]. Furthermore, desialylated immune complexes enhanced osteoclastogenesis and mice treated with the sialic acid precursor N-acetylmannosamine increased IgG sialylation leading to decreased bone loss [226]. Moreover, increased Fab glycosylation of ACPA modulated their binding to citrullinated antigens [227].

These studies clearly demonstrate that appropriate modification of the Fc glycosylation status of antibodies could very well attenuate the effector phase of arthritis. In this direction, a bacterial enzyme that can cleave the IgG-Fc sugar molecules specifically was tested. EndoS is a secreted endoglycosidase enzyme from the Gram-positive bacteria Streptococcus pyogenes (Group A streptococcus), which specifically hydrolyzes the conserved $\beta-1,4-d i-N$-acetylchitobiose core of the IgG-Fc [228], and it is highly specific for human IgG [229]. Removal of the Fc glycan with EndoS causes the Fc domains to deform, leading to diminished binding to $\mathrm{Fc} \gamma$ receptors [230] and complement activation. EndoS treatment abrogated arthritogenicity of anti-CII mAbs [231]. Furthermore, EndoS treatment disturbed the 
formation of stable and larger immune complexes on the articular cartilage surface by cleaving specific sugars present on IgG-Fc, which led to attenuation of joint inflammation [232]. These studies open up a new strategy for specifically modifying the IgG-Fc sugars for the treatment of arthritis patients in the future.

\section{Conclusion}

RF and ACPA are the two most iconic autoantibodies in diagnosis facilitating treatment and prognosis of RA. RF and ACPA have similar diagnostic values. However, ACPAs are certainly more specific than IgM-RF, but in most studies, IgM-RF has been shown to be more sensitive than ACPA. Moreover, IgA-RF as well as IgG-RF are more specific than the IgM isotype alone. However, because of the higher sensitivity and specificity, ACPA has more diagnostic value than RF. Detection of both RF and ACPA can predict the extent of joint damage, and RF is also associated with extraarticular lesions. Moreover, differential alterations in the levels of these two autoantibodies during treatment reflect different underlying mechanisms operating during RA. High affinity autoantibodies are synthesized by plasma cells present in the specialized lymphoid structures (GCs) that are present in secondary lymphoid organs as well as in the inflamed joint tissues. These autoantibodies can induce cartilage damage both in an inflammation-dependent and an inflammation-independent manner. Variations in IgGFc glycosylation affect autoantibody effector functions and subsequent inflammation that are dependent on binding to the effector components $(\mathrm{Fc} \gamma \mathrm{R}$ and complement) of the end-stage effector phase of arthritis. Hence, modification of IgG-Fc N-glycans by glycoengineering or by using specific glycolytic enzymes could be a useful strategy for the treatment of several IgG-dependent autoimmune pathologies.

\section{Conflicts of Interest}

The authors declare that they have no conflicts of interest.

\section{Acknowledgments}

We would like to thank the Southern Medical University, Guangzhou, China, for the start-up grants (C1034211, C1051004) and the international exploration grant (C1051427).

\section{References}

[1] S. E. Gabriel, "The epidemiology of rheumatoid arthritis," Rheumatic Diseases Clinics of North America, vol. 27, no. 2, pp. 269-281, 2001.

[2] D. Mewar and A. G. Wilson, "Autoantibodies in rheumatoid arthritis: a review," Biomedicine \& Pharmacotherapy, vol. 60, no. 10, pp. 648-655, 2006.

[3] S. Das and P. Padhan, "An overview of the extraarticular involvement in rheumatoid arthritis and its management," Journal of Pharmacology and Pharmacotherapeutics, vol. 8, no. 3, pp. 81-86, 2017.

[4] A. Willemze, L. A. Trouw, R. E. M. Toes, and T. W. J. Huizinga, "The influence of ACPA status and characteristics on the course of RA," Nature Reviews Rheumatology, vol. 8, no. 3, pp. 144-152, 2012.

[5] H. M. Rose, C. Ragan, E. Pearce, and M. O. Lipman, "Differential agglutination of normal and sensitized sheep erythrocytes by sera of patients with rheumatoid arthritis," Proceedings of the Society for Experimental Biology and Medicine, vol. 68, no. 1, pp. 1-6, 1948.

[6] D. G. Fatkins and W. Zheng, "Substituting $\mathrm{N}^{\varepsilon}$-thioacetyllysine for $\mathrm{N}^{\varepsilon}$-acetyl-lysine in peptide substrates as a general approach to inhibiting human $\mathrm{NAD}^{+}$-dependent protein deacetylases," International Journal of Molecular Sciences, vol. 9, no. 1, pp. 1-11, 2008.

[7] R. Ree, S. Varland, and T. Arnesen, "Spotlight on protein N-terminal acetylation," Experimental \& Molecular Medicine, vol. 50, no. 7, p. 90, 2018.

[8] L. A. Trouw, T. W. J. Huizinga, and R. E. M. Toes, "Autoimmunity in rheumatoid arthritis: different antigens-common principles," Annals of the Rheumatic Diseases, vol. 72, Supplement 2, pp. ii132-ii136, 2013.

[9] J. S. Courtenay, M. J. Dallman, A. D. Dayan, A. Martin, and B. Mosedale, "Immunisation against heterologous type II collagen induces arthritis in mice," Nature, vol. 283, no. 5748, pp. 666-668, 1980.

[10] R. Pfeifle, T. Rothe, N. Ipseiz et al., "Regulation of autoantibody activity by the IL-23- $\mathrm{T}_{\mathrm{H}} 17$ axis determines the onset of autoimmune disease," Nature Immunology, vol. 18, no. 1, pp. 104-113, 2017.

[11] J. M. Stuart and F. J. Dixon, "Serum transfer of collageninduced arthritis in mice," The Journal of Experimental Medicine, vol. 158, no. 2, pp. 378-392, 1983.

[12] H. A. Ménard, E. Lapointe, M. D. Rochdi, and Z. J. Zhou, "Insights into rheumatoid arthritis derived from the Sa immune system," Arthritis Research, vol. 2, no. 6, pp. 429-432, 2000.

[13] G. A. Schellekens, H. Visser, B. A. W. de Jong et al., "The diagnostic properties of rheumatoid arthritis antibodies recognizing a cyclic citrullinated peptide," Arthritis \& Rheumatism, vol. 43, no. 1, pp. 155-163, 2000.

[14] S. Monti, C. Montecucco, S. Bugatti, and R. Caporali, "Rheumatoid arthritis treatment: the earlier the better to prevent joint damage," RMD Open, vol. 1, article e000057, Supplement 1, 2015.

[15] T. Neogi, D. Aletaha, A. J. Silman et al., "The 2010 American College of Rheumatology/European League Against Rheumatism classification criteria for rheumatoid arthritis: phase 2 methodological report," Arthritis and Rheumatism, vol. 62, no. 9, pp. 2582-2591, 2010.

[16] R. L. F. Nienhuis, E. Mandema, and C. Smids, "New serum factor in patients with rheumatoid arthritis: the antiperinuclear factor," Annals of the Rheumatic Diseases, vol. 23, pp. 302-305, 1964.

[17] B. J. Young, R. K. Mallya, R. D. Leslie, C. J. Clark, and T. J. Hamblin, "Anti-keratin antibodies in rheumatoid arthritis," British Medical Journal, vol. 2, no. 6182, pp. 97-99, 1979.

[18] C. Vincent, M. Simon, M. Sebbag et al., "Immunoblotting detection of autoantibodies to human epidermis filaggrin: a new diagnostic test for rheumatoid arthritis," The Journal of Rheumatology, vol. 25, no. 5, pp. 838-846, 1998.

[19] N. Després, G. Boire, F. J. Lopez-Longo, and H. A. Ménard, "The Sa system: a novel antigen-antibody system specific for rheumatoid arthritis," The Journal of Rheumatology, vol. 21, no. 6, pp. 1027-1033, 1994. 
[20] F. Pratesi, F. Panza, I. Paolini et al., "Fingerprinting of anti-citrullinated protein antibodies (ACPA): specificity, isotypes and subclasses," Lupus, vol. 24, no. 4-5, pp. 433-441, 2015.

[21] M. Gogól, "Citrullination - small change with a great consequence," Folia Biologica et Oecologica, vol. 9, no. 1, pp. 17-25, 2013.

[22] Y. Tabushi, T. Nakanishi, T. Takeuchi et al., "Detection of citrullinated proteins in synovial fluids derived from patients with rheumatoid arthritis by proteomics-based analysis," Annals of Clinical Biochemistry, vol. 45, no. 4, pp. 413-417, 2008.

[23] C. Iobagiu, A. Magyar, L. Nogueira et al., "The antigen specificity of the rheumatoid arthritis-associated ACPA directed to citrullinated fibrin is very closely restricted," Journal of Autoimmunity, vol. 37, no. 4, pp. 263-272, 2011.

[24] S. S. Farid, G. Azizi, and A. Mirshafiey, "Anti-citrullinated protein antibodies and their clinical utility in rheumatoid arthritis," International Journal of Rheumatic Diseases, vol. 16, no. 4, pp. 379-386, 2013.

[25] G. Valesini, M. C. Gerardi, C. Iannuccelli, V. A. Pacucci, M. Pendolino, and Y. Shoenfeld, "Citrullination and autoimmunity," Autoimmunity Reviews, vol. 14, no. 6, pp. 490497, 2015.

[26] M. Simon, E. Girbal, M. Sebbag et al., "The cytokeratin filament-aggregating protein filaggrin is the target of the socalled "antikeratin antibodies," autoantibodies specific for rheumatoid arthritis," The Journal of Clinical Investigation, vol. 92, no. 3, pp. 1387-1393, 1993.

[27] E. R. Vossenaar, N. Després, E. Lapointe et al., "Rheumatoid arthritis specific anti-Sa antibodies target citrullinated vimentin," Arthritis Research \& Therapy, vol. 6, no. 2, article R142, 2004.

[28] K. Lundberg, C. Bengtsson, N. Kharlamova et al., "Genetic and environmental determinants for disease risk in subsets of rheumatoid arthritis defined by the anticitrullinated protein/peptide antibody fine specificity profile," Annals of the Rheumatic Diseases, vol. 72, no. 5, pp. 652-658, 2013.

[29] K. Lundberg, A. Kinloch, B. A. Fisher et al., "Antibodies to citrullinated $\alpha$-enolase peptide 1 are specific for rheumatoid arthritis and cross-react with bacterial enolase," Arthritis \& Rheumatism, vol. 58, no. 10, pp. 3009-3019, 2008.

[30] C. Masson-Bessière, M. Sebbag, E. Girbal-Neuhauser et al., "The major synovial targets of the rheumatoid arthritisspecific antifilaggrin autoantibodies are deiminated forms of the $\alpha$ - and $\beta$-chains of fibrin," The Journal of Immunology, vol. 166, no. 6, pp. 4177-4184, 2001.

[31] J. J. Malemba, J. M. Mbuyi-Muamba, J. Mukaya, X. Bossuyt, P. Verschueren, and R. Westhovens, "The epidemiology of rheumatoid arthritis in Kinshasa, Democratic Republic of Congo-a population-based study," Rheumatology, vol. 51, no. 9, pp. 1644-1647, 2012.

[32] A. Solomon, B. F. Christian, P. H. Dessein, and A. E. Stanwix, "The need for tighter rheumatoid arthritis control in a South African public health care center," Seminars in Arthritis and Rheumatism, vol. 35, no. 2, pp. 122-131, 2005.

[33] L. Klareskog, J. Rönnelid, K. Lundberg, L. Padyukov, and L. Alfredsson, "Immunity to citrullinated proteins in rheumatoid arthritis," Annual Review of Immunology, vol. 26, no. 1, pp. 651-675, 2008.

[34] J. T. Gran, G. Husby, and E. Thorsby, "The association between rheumatoid arthritis and the HLA antigen DR4,"
Annals of the Rheumatic Diseases, vol. 42, no. 3, pp. 292296, 1983 .

[35] M. Singwe-Ngandeu, A. Finckh, S. Bas, J. M. Tiercy, and C. Gabay, "Diagnostic value of anti-cyclic citrullinated peptides and association with HLA-DRB1 shared epitope alleles in African rheumatoid arthritis patients," Arthritis Research \& Therapy, vol. 12, no. 2, article R36, 2010.

[36] V. M. Holers, "Autoimmunity to citrullinated proteins and the initiation of rheumatoid arthritis," Current Opinion in Immunology, vol. 25, no. 6, pp. 728-735, 2013.

[37] R. Kocijan, U. Harre, and G. Schett, "ACPA and bone loss in rheumatoid arthritis," Current Rheumatology Reports, vol. 15, no. 10, p. 366, 2013.

[38] H. L. Wright, R. J. Moots, and S. W. Edwards, "The multifactorial role of neutrophils in rheumatoid arthritis," Nature Reviews Rheumatology, vol. 10, no. 10, pp. 593-601, 2014.

[39] C. S. Chowdhury, S. Giaglis, U. A. Walker, A. Buser, S. Hahn, and P. Hasler, "Enhanced neutrophil extracellular trap generation in rheumatoid arthritis: analysis of underlying signal transduction pathways and potential diagnostic utility," Arthritis Research \& Therapy, vol. 16, no. 3, article R122, 2014.

[40] M. K. Verheul, U. Fearon, L. A. Trouw, and D. J. Veale, "Biomarkers for rheumatoid and psoriatic arthritis," Clinical Immunology, vol. 161, no. 1, pp. 2-10, 2015.

[41] F. Ingegnoli, R. Castelli, and R. Gualtierotti, "Rheumatoid factors: clinical applications," Disease Markers, vol. 35, no. 6, 734 pages, 2013.

[42] R. A. Moura, L. Graca, and J. E. Fonseca, "To B or not to B the conductor of rheumatoid arthritis orchestra," Clinical Reviews in Allergy and Immunology, vol. 43, no. 3, pp. 281291, 2012.

[43] S. F. Nielsen, S. E. Bojesen, P. Schnohr, and B. G. Nordestgaard, "Elevated rheumatoid factor and long term risk of rheumatoid arthritis: a prospective cohort study," BMJ, vol. 345, article e5244, 2012.

[44] M. Schoels, C. Bombardier, and D. Aletaha, "Diagnostic and prognostic value of antibodies and soluble biomarkers in undifferentiated peripheral inflammatory arthritis: a systematic review," The Journal of Rheumatology, vol. 87, pp. 20-25, 2011.

[45] K. Nishimura, D. Sugiyama, Y. Kogata et al., "Metaanalysis: diagnostic accuracy of anti-cyclic citrullinated peptide antibody and rheumatoid factor for rheumatoid arthritis," Annals of Internal Medicine, vol. 146, no. 11, pp. 797-808, 2007.

[46] M. Ramos-Casals, J. H. Stone, M. C. Cid, and X. Bosch, "The cryoglobulinaemias," The Lancet, vol. 379, no. 9813, pp. 348360, 2012.

[47] Y. Renaudineau, C. Jamin, A. Saraux, and P. Youinou, "Rheumatoid factor on a daily basis," Autoimmunity, vol. 38, no. 1, pp. 11-16, 2005.

[48] Y. S. Shin, J. H. Choi, D. H. Nahm, H. S. Park, J. H. Cho, and C. H. Suh, "Rheumatoid factor is a marker of disease severity in Korean rheumatoid arthritis," Yonsei Medical Journal, vol. 46, no. 4, pp. 464-470, 2005.

[49] I. Salehi-Abari, "2016 ACR/EULAR revised criteria for too early diagnosis of rheumatoid arthritis," Autoimmune Diseases and Therapeutic, vol. 3, no. 1, p. 120, 2016.

[50] H. A. Chen, K. C. Lin, C. H. Chen et al., "The effect of etanercept on anti-cyclic citrullinated peptide antibodies and rheumatoid factor in patients with rheumatoid arthritis," Annals of the Rheumatic Diseases, vol. 65, no. 1, pp. 35-39, 2006. 
[51] L. De Rycke, X. Verhelst, E. Kruithof et al., "Rheumatoid factor, but not anti-cyclic citrullinated peptide antibodies, is modulated by infliximab treatment in rheumatoid arthritis," Annals of the Rheumatic Diseases, vol. 64, no. 2, pp. 299302, 2005.

[52] V. Nell-Duxneuner, K. Machold, T. Stamm et al., "Autoantibody profiling in patients with very early rheumatoid arthritis: a follow-up study," Annals of the Rheumatic Diseases, vol. 69, no. 1, pp. 169-174, 2010.

[53] D. A. Carson, A. S. Bayer, R. A. Eisenberg, S. Lawrance, and A. Theofilopoulos, "IgG rheumatoid factor in subacute bacterial endocarditis: relationship to IgM rheumatoid factor and circulating immune complexes," Clinical and Experimental Immunology, vol. 31, no. 1, pp. 100-103, 1978.

[54] A. Kaushik, U. B. Singh, C. Porwal et al., "Diagnostic potential of $16 \mathrm{kDa}$ (HspX, $\alpha$-crystalline) antigen for serodiagnosis of tuberculosis," The Indian Journal of Medical Research, vol. 135, no. 5, pp. 771-777, 2012.

[55] M. Børretzen, C. Chapman, J. B. Natvig, and K. M. Thompson, "Differences in mutational patterns between rheumatoid factors in health and disease are related to variable heavy chain family and germ-line gene usage," European Journal of Immunology, vol. 27, no. 3, pp. 735-741, 1997.

[56] J. C. Edwards and G. Cambridge, "Rheumatoid arthritis: the predictable effect of small immune complexes in which antibody is also antigen," British Journal of Rheumatology, vol. 37, no. 2, pp. 126-130, 1998.

[57] R. S. de Brito, D. C. Baldo, and L. E. C. Andrade, "Clinical and pathophysiologic relevance of autoantibodies in rheumatoid arthritis," Advances in Rheumatology, vol. 59, no. 1, p. 2, 2019.

[58] Y. W. Song and E. H. Kang, "Autoantibodies in rheumatoid arthritis: rheumatoid factors and anticitrullinated protein antibodies," QJM, vol. 103, no. 3, pp. 139-146, 2010.

[59] E. Aleyd, M. Al, C. W. Tuk, C. J. van der Laken, and M. van Egmond, "IgA complexes in plasma and synovial fluid of patients with rheumatoid arthritis induce neutrophil extracellular traps via Fc $\alpha \mathrm{RI}$," The Journal of Immunology, vol. 197, no. 12, pp. 4552-4559, 2016.

[60] K. Amara, E. Clay, L. Yeo et al., "B cells expressing the IgA receptor FCRL4 participate in the autoimmune response in patients with rheumatoid arthritis," Journal of Autoimmunity, vol. 81, pp. 34-43, 2017.

[61] F. Bobbio-Pallavicini, R. Caporali, C. Alpini et al., "High IgA rheumatoid factor levels are associated with poor clinical response to tumour necrosis factor $\alpha$ inhibitors in rheumatoid arthritis," Annals of the Rheumatic Diseases, vol. 66, no. 3, pp. 302-307, 2007.

[62] T. Jónsson, S. Arinbjarnarson, J. Thorsteinsson et al., "Raised IgA rheumatoid factor (RF) but not IgM RF or IgG RF is associated with extra-articular manifestations in rheumatoid arthritis," Scandinavian Journal of Rheumatology, vol. 24, no. 6, pp. 372-375, 1995.

[63] J. Sokolove, D. S. Johnson, L. J. Lahey et al., "Rheumatoid factor as a potentiator of anti-citrullinated protein antibodymediated inflammation in rheumatoid arthritis," Arthritis \& Rhematology, vol. 66, no. 4, pp. 813-821, 2014.

[64] L. H. D. van Tuyl, W. F. Lems, P. J. S. M. Kerstens, A. E. Voskuyl, B. A. C. Dijkmans, and M. Boers, "IgM-rheumatoid factor and anti-cyclic citrullinated peptide decrease by $50 \%$ during intensive treatment in early rheumatoid arthritis," Annals of the Rheumatic Diseases, vol. 68, no. 10, pp. 16521653, 2009.
[65] D. T. Felson, J. J. Anderson, M. Boers et al., "The American College of Rheumatology preliminary core set of disease activity measures for rheumatoid arthritis clinical trials," Arthritis \& Rheumatism, vol. 36, no. 6, pp. 729740, 1993.

[66] J. T. Giles, S. J. Bartlett, R. Andersen, R. Thompson, K. R. Fontaine, and J. M. Bathon, "Association of body fat with C-reactive protein in rheumatoid arthritis," Arthritis \& Rheumatism, vol. 58, no. 9, pp. 2632-2641, 2008.

[67] H. S. Cha, T. J. Kim, J. Y. Kim et al., “Autoantibodies to glucose-6-phosphate isomerase are elevated in the synovial fluid of rheumatoid arthritis patients," Scandinavian Journal of Rheumatology, vol. 33, no. 3, pp. 179-184, 2004.

[68] M. Schaller, D. R. Burton, and H. J. Ditzel, “Autoantibodies to GPI in rheumatoid arthritis: linkage between an animal model and human disease," Nature Immunology, vol. 2, no. 8, pp. 746-753, 2001.

[69] M. Hashimoto, K. Hirota, H. Yoshitomi et al., "Complement drives Th17 cell differentiation and triggers autoimmune arthritis," The Journal of Experimental Medicine, vol. 207, no. 6, pp. 1135-1143, 2010.

[70] K. J. Katschke Jr., K. Y. Helmy, M. Steffek et al., “A novel inhibitor of the alternative pathway of complement reverses inflammation and bone destruction in experimental arthritis," The Journal of Experimental Medicine, vol. 204, no. 6, pp. 1319-1325, 2007.

[71] S. Kleinau, P. Martinsson, and B. Heyman, "Induction and suppression of collagen-induced arthritis is dependent on distinct $\mathrm{f} c \gamma$ receptors," The Journal of Experimental Medicine, vol. 191, no. 9, pp. 1611-1616, 2000.

[72] D. Schubert, B. Maier, L. Morawietz, V. Krenn, and T. Kamradt, "Immunization with glucose-6-phosphate isomerase induces $\mathrm{T}$ cell-dependent peripheral polyarthritis in genetically unaltered mice," The Journal of Immunology, vol. 172, no. 7, pp. 4503-4509, 2004.

[73] L. Bruns, O. Frey, L. Morawietz, C. Landgraf, R. Volkmer, and T. Kamradt, "Immunization with an immunodominant selfpeptide derived from glucose-6-phosphate isomerase induces arthritis in DBA/1 mice," Arthritis Research \& Therapy, vol. 11, no. 4, article R117, 2009.

[74] K. Iwanami, I. Matsumoto, Y. Yoshiga et al., "Altered peptide ligands inhibit arthritis induced by glucose-6-phosphate isomerase peptide," Arthritis Research \& Therapy, vol. 11, no. 6, article R167, 2009.

[75] D. Schubert, M. Schmidt, D. Zaiss, P. R. Jungblut, and T. Kamradt, "Autoantibodies to GPI and creatine kinase in RA,” Nature Immunology, vol. 3, no. 5, p. 411, 2002.

[76] F. Jouen, O. Vittecoq, F. Leguillou et al., "Diagnostic and prognostic values of anti glucose-6-phosphate isomerase antibodies in community-recruited patients with very early arthritis," Clinical and Experimental Immunology, vol. 137, no. 3, pp. 606-611, 2004.

[77] M. Schaller, W. Stohl, S. M. Tan, V. M. Benoit, D. M. Hilbert, and H. J. Ditzel, "Raised levels of anti-glucose-6-phosphate isomerase IgG in serum and synovial fluid from patients with inflammatory arthritis," Annals of the Rheumatic Diseases, vol. 64, no. 5, pp. 743-749, 2005.

[78] L. A. Trouw, T. Rispens, and R. E. M. Toes, "Beyond citrullination: other post-translational protein modifications in rheumatoid arthritis," Nature Reviews Rheumatology, vol. 13, no. 6, pp. 331-339, 2017. 
[79] A. Montes, C. Regueiro, E. Perez-Pampin, M. D. Boveda, J. J. Gomez-Reino, and A. Gonzalez, "Anti-carbamylated protein antibodies as a reproducible independent type of rheumatoid arthritis autoantibodies," PLoS One, vol. 11, no. 8, article e0161141, 2016.

[80] P. Mydel, Z. Wang, M. Brisslert et al., "Carbamylationdependent activation of $\mathrm{T}$ cells: a novel mechanism in the pathogenesis of autoimmune arthritis," The Journal of Immunology, vol. 184, no. 12, pp. 6882-6890, 2010.

[81] M. K. Verheul, A. Yee, A. Seaman et al., "Identification of carbamylated alpha 1 anti-trypsin (A1AT) as an antigenic target of anti-CarP antibodies in patients with rheumatoid arthritis," Journal of Autoimmunity, vol. 80, pp. 77-84, 2017.

[82] M. K. Verheul, S. J. H. van Erp, D. van der Woude et al., "Anti-carbamylated protein antibodies: a specific hallmark for rheumatoid arthritis. Comparison to conditions known for enhanced carbamylation; renal failure, smoking and chronic inflammation," Annals of the Rheumatic Diseases, vol. 75, no. 8, pp. 1575-1576, 2016.

[83] J. Shi, R. Knevel, P. Suwannalai et al., “Autoantibodies recognizing carbamylated proteins are present in sera of patients with rheumatoid arthritis and predict joint damage," Proceedings of the National Academy of Sciences of the United States of America, vol. 108, no. 42, pp. 17372-17377, 2011.

[84] J. Shi, H. W. van Steenbergen, J. A. B. van Nies et al., “The specificity of anti-carbamylated protein antibodies for rheumatoid arthritis in a setting of early arthritis," Arthritis Research \& Therapy, vol. 17, no. 1, p. 339, 2015.

[85] M. Juarez, H. Bang, F. Hammar et al., "Identification of novel antiacetylated vimentin antibodies in patients with early inflammatory arthritis," Annals of the Rheumatic Diseases, vol. 75, no. 6, pp. 1099-1107, 2016.

[86] X. J. Yang and E. Seto, "Lysine acetylation: codified crosstalk with other posttranslational modifications," Molecular Cell, vol. 31, no. 4, pp. 449-461, 2008.

[87] L. Göschl, T. Preglej, P. Hamminger et al., "A T cell-specific deletion of HDAC1 protects against experimental autoimmune encephalomyelitis," Journal of Autoimmunity, vol. 86, pp. 51-61, 2018.

[88] G. M. Simon, J. Cheng, and J. I. Gordon, "Quantitative assessment of the impact of the gut microbiota on lysine $\varepsilon$-acetylation of host proteins using gnotobiotic mice," Proceedings of the National Academy of Sciences of the United States of America, vol. 109, no. 28, pp. 11133-11138, 2012.

[89] B. Svensson, I. Hafström, M. C. Erlandsson, K. Forslind, and M. I. Bokarewa, "Smoking in combination with antibodies to cyclic citrullinated peptides is associated with persistently high levels of survivin in early rheumatoid arthritis: a prospective cohort study," Arthritis Research \& Therapy, vol. 16, no. 1, article R12, 2014.

[90] D. Iacono, E. Favoino, A. Borgia et al., "Low mortality rate in Italian rheumatoid arthritis patients from a tertiary center: putative implication of a low anti-carbamylated protein antibodies prevalence," Open Access Rheumatology: Research and Reviews, vol. 10, pp. 129-134, 2018.

[91] A. G. Pratt, D. Lendrem, B. Hargreaves, O. Aslam, J. B. Galloway, and J. D. Isaacs, "Components of treatment delay in rheumatoid arthritis differ according to autoantibody status: validation of a single-centre observation using national audit data," Rheumatology, vol. 55, no. 10, pp. 1843-1848, 2016.

[92] A. Emamifar, J. Hangaard, and H. I. M. Jensen, “Thyroid disorders in patients with newly diagnosed rheumatoid arthritis is associated with poor initial treatment response evaluated by disease activity score in 28 joints-C-reactive protein (DAS28-CRP): An observational cohort study," Medicine, vol. 96, no. 43, article e8357, 2017.

[93] W. H. Bos, G. M. Bartelds, G. J. Wolbink et al., "Differential response of the rheumatoid factor and anticitrullinated protein antibodies during adalimumab treatment in patients with rheumatoid arthritis," The Journal of Rheumatology, vol. 35, no. 10, pp. 1972-1977, 2008.

[94] S. Ajeganova, H. W. van Steenbergen, M. K. Verheul et al., "The association between anti-carbamylated protein (antiCarP) antibodies and radiographic progression in early rheumatoid arthritis: a study exploring replication and the added value to ACPA and rheumatoid factor," Annals of the Rheumatic Diseases, vol. 76, no. 1, pp. 112-118, 2017.

[95] A. Bruns, P. Nicaise-Roland, G. Hayem et al., "Prospective cohort study of effects of infliximab on rheumatoid factor, anti-cyclic citrullinated peptide antibodies and antinuclear antibodies in patients with long-standing rheumatoid arthritis," Joint Bone Spine, vol. 76, no. 3, pp. 248-253, 2009.

[96] C. Dejaco, C. Duftner, W. Klotz, M. Schirmer, and M. Herold, "Antibodies against mutated citrullinated vimentin fail to predict anti-TNF $\alpha$ treatment response in rheumatoid arthritis," Scandinavian Journal of Rheumatology, vol. 38, no. 1, pp. 66-67, 2009.

[97] M. Ponikowska, J. Świerkot, B. Nowak, L. Korman, and P. Wiland, "Autoantibody and metalloproteinase activity in early arthritis," Clinical Rheumatology, vol. 38, no. 3, pp. 827-834, 2019.

[98] C. Regueiro, A. M. Ortiz, M. D. Boveda, S. Castañeda, I. Gonzalez-Alvaro, and A. Gonzalez, "Association of high titers of anti-carbamylated protein antibodies with decreased bone mineral density in early arthritis patients," PLoS One, vol. 13, no. 8, article e0202583, 2018.

[99] C. Regueiro, L. Nuño, A. M. Ortiz et al., "Value of measuring anti-carbamylated protein antibodies for classification on early arthritis patients," Scientific Reports, vol. 7, no. 1, article 12023, 2017.

[100] L. Vidal-Bralo, E. Perez-Pampin, C. Regueiro et al., "Anticarbamylated protein autoantibodies associated with mortality in Spanish rheumatoid arthritis patients," PLoS One, vol. 12, no. 7, article e0180144, 2017.

[101] F. R. Spinelli, A. Pecani, F. Ciciarello et al., "Association between antibodies to carbamylated proteins and subclinical atherosclerosis in rheumatoid arthritis patients," $B M C$ Musculoskeletal Disorders, vol. 18, no. 1, p. 214, 2017.

[102] A. Pecani, C. Alessandri, F. R. Spinelli et al., "Prevalence, sensitivity and specificity of antibodies against carbamylated proteins in a monocentric cohort of patients with rheumatoid arthritis and other autoimmune rheumatic diseases," Arthritis Research \& Therapy, vol. 18, no. 1, p. 276, 2016.

[103] E. Alemao, Z. Guo, M. L. Frits, C. K. Iannaccone, N. A. Shadick, and M. E. Weinblatt, "Association of anti-cyclic citrullinated protein antibodies, erosions, and rheumatoid factor with disease activity and work productivity: A patient registry study," Seminars in Arthritis and Rheumatism, vol. 47, no. 5, pp. 630-638, 2018.

[104] T. R. Mikuls, J. B. Payne, F. Yu et al., "Periodontitis and Porphyromonas gingivalis in patients with rheumatoid arthritis," Arthritis \& Rhematology, vol. 66, no. 5, pp. 1090-1100, 2014.

[105] T. R. Mikuls, V. M. Holers, L. Parrish et al., "Anti-cyclic citrullinated peptide antibody and rheumatoid factor isotypes 
in African Americans with early rheumatoid arthritis," Arthritis and Rheumatism, vol. 54, no. 9, pp. 3057-3059, 2006.

[106] L. E. Wong, W. T. Huang, J. E. Pope et al., "Effect of age at menopause on disease presentation in early rheumatoid arthritis: results from the Canadian Early Arthritis Cohort," Arthritis Care \& Research, vol. 67, no. 5, pp. 616-623, 2015.

[107] H. F. Oliveira, T. R. de Souza, C. N. Carvalho et al., "Serologic profile and clinical markers of Sjögren syndrome in patients with rheumatoid arthritis," Oral Surgery, Oral Medicine, Oral Pathology, Oral Radiology, vol. 119, no. 6, pp. 628-635, 2015.

[108] Y. Wang, L. Chen, F. Li et al., "TLR4 rs41426344 increases susceptibility of rheumatoid arthritis (RA) and juvenile idiopathic arthritis (JIA) in a central south Chinese Han population," Pediatric Rheumatology Online Journal, vol. 15, no. 1, p. 12, 2017.

[109] T. Zhu and L. Feng, "Comparison of anti-mutated citrullinated vimentin, anti-cyclic citrullinated peptides, anti-glucose-6-phosphate isomerase and anti-keratin antibodies and rheumatoid factor in the diagnosis of rheumatoid arthritis in Chinese patients," International Journal of Rheumatic Diseases, vol. 16, no. 2, pp. 157-161, 2013.

[110] M. Begum, H. Sattar, S. A. Haq et al., "Study on association of human leukocyte antigen-DRB1 alleles amongst Bangladeshi patients with rheumatoid arthritis," International Journal of Rheumatic Diseases, vol. 21, no. 8, pp. 1543-1547, 2018.

[111] Y. Hamamoto, H. Ito, M. Furu et al., "Serological and progression differences of joint destruction in the wrist and the feet in rheumatoid arthritis - a cross-sectional cohort study," PLoS One, vol. 10, no. 8, article e0136611, 2015.

[112] S. Onishi, T. Yoshio, T. Nagashima, and S. Minota, "Decrease in the levels of anti-cyclic citrullinated peptide antibody in Japanese patients with rheumatoid arthritis who responded to anti-tumor necrosis factor- $\alpha$," Modern Rheumatology, vol. 20, no. 5, pp. 528-530, 2010.

[113] T. Furuya, I. Matsumoto, N. Tsuchiya et al., "Anti-glucose6-phosphate isomerase, anti-cyclic citrullinated peptide antibodies and HLA-DRB1 genotypes in Japanese patients with early rheumatoid arthritis," Clinical and Experimental Rheumatology, vol. 26, no. 5, pp. 918-921, 2008.

[114] P. Rojanasantikul, P. Pattrapornpisut, K. Anuruckparadorn, and W. Katchamart, "The performance of a point of care test for detection of anti-mutated citrullinated vimentin and rheumatoid factor in early rheumatoid arthritis," Clinical Rheumatology, vol. 33, no. 7, pp. 919-923, 2014.

[115] Y. Braun-Moscovici, D. Markovits, O. Zinder et al., "Anticyclic citrullinated protein antibodies as a predictor of response to anti-tumor necrosis factor- $\alpha$ therapy in patients with rheumatoid arthritis," The Journal of Rheumatology, vol. 33, no. 3, pp. 497-500, 2006.

[116] V. K. Mohan, N. Ganesan, R. Gopalakrishnan, and V. Venkatesan, "HLA-DRB1 shared epitope alleles in patients with rheumatoid arthritis: relation to autoantibodies and disease severity in a south Indian population," International Journal of Rheumatic Diseases, vol. 20, no. 10, pp. 14921498, 2017.

[117] P. W. A. Meyer, M. T. M. Ally, B. Hodkinson, R. Anderson, and M. Tikly, "Comparison of the diagnostic potential of three anti-citrullinated protein antibodies as adjuncts to rheumatoid factor and CCP in a cohort of South African rheumatoid arthritis patients," Rheumatology International, vol. 38, no. 6, pp. 993-1001, 2018.
[118] C. L. Too, S. Murad, M. Hansson et al., "Differences in the spectrum of anti-citrullinated protein antibody fine specificities between Malaysian and Swedish patients with rheumatoid arthritis: implications for disease pathogenesis," Arthritis \& Rheumatology, vol. 69, no. 1, pp. 58-69, 2017.

[119] D. van der Woude, S. Rantapaa-Dahlqvist, A. Ioan-Facsinay et al., "Epitope spreading of the anti-citrullinated protein antibody response occurs before disease onset and is associated with the disease course of early arthritis," Annals of the Rheumatic Diseases, vol. 69, no. 8, pp. 1554-1561, 2010.

[120] A. H. Hensvold, V. Joshua, W. Li et al., "Serum RANKL levels associate with anti- citrullinated protein antibodies in early untreated rheumatoid arthritis and are modulated following methotrexate," Arthritis Research \& Therapy, vol. 17, no. 1, p. 239, 2016.

[121] M. Brink, M. K. Verheul, J. Rönnelid et al., “Anti-carbamylated protein antibodies in the pre-symptomatic phase of rheumatoid arthritis, their relationship with multiple anticitrulline peptide antibodies and association with radiological damage," Arthritis Research \& Therapy, vol. 17, no. 1, p. 25, 2015.

[122] R. Klaasen, T. Cantaert, C. A. Wijbrandts et al., "The value of rheumatoid factor and anti-citrullinated protein antibodies as predictors of response to infliximab in rheumatoid arthritis: an exploratory study," Rheumatology, vol. 50, no. 8, pp. 1487-1493, 2011.

[123] E. C. de Moel, V. F. A. M. Derksen, G. Stoeken et al., "Baseline autoantibody profile in rheumatoid arthritis is associated with early treatment response but not long-term outcomes," Arthritis Research \& Therapy, vol. 20, no. 1, p. 33, 2018.

[124] R. M. ten Brinck, H. W. van Steenbergen, M. A. M. van Delft et al., "The risk of individual autoantibodies, autoantibody combinations and levels for arthritis development in clinically suspect arthralgia," Rheumatology, vol. 56, no. 12, pp. 2145-2153, 2017.

[125] M. A. M. van Delft, M. K. Verheul, L. E. Burgers et al., "The isotype and IgG subclass distribution of anti-carbamylated protein antibodies in rheumatoid arthritis patients," Arthritis Research \& Therapy, vol. 19, no. 1, p. 190, 2017.

[126] Z. Szekanecz, Z. Szabó, M. Zeher et al., "Superior performance of the CCP3.1 test compared to CCP2 and MCV in the rheumatoid factor-negative RA population," Immunologic Research, vol. 56, no. 2-3, pp. 439-443, 2013.

[127] C. Alessandri, M. Bombardieri, N. Papa et al., "Decrease of anti-cyclic citrullinated peptide antibodies and rheumatoid factor following anti-TNF $\alpha$ therapy (infliximab) in rheumatoid arthritis is associated with clinical improvement," Annals of the Rheumatic Diseases, vol. 63, no. 10, pp. 12181221, 2004.

[128] K. N. Verpoort, K. Cheung, A. Ioan-Facsinay et al., "Fine specificity of the anti-citrullinated protein antibody response is influenced by the shared epitope alleles," Arthritis \& Rheumatism, vol. 56, no. 12, pp. 3949-3952, 2007.

[129] A. M. Quirke, E. Perry, A. Cartwright et al., "Bronchiectasis is a model for chronic bacterial infection inducing autoimmunity in rheumatoid arthritis," Arthritis \& Rhematology, vol. 67, no. 9, pp. 2335-2342, 2015.

[130] C. Fernandes-Cerqueira, E. Ossipova, S. Gunasekera et al., "Targeting of anti-citrullinated protein/peptide antibodies in rheumatoid arthritis using peptides mimicking endogenously citrullinated fibrinogen antigens," Arthritis Research \& Therapy, vol. 17, no. 1, p. 155, 2015. 
[131] V. Joshua, L. Schobers, P. J. Titcombe et al., "Antibody responses to de novo identified citrullinated fibrinogen peptides in rheumatoid arthritis and visualization of the corresponding B cells," Arthritis Research \& Therapy, vol. 18 , no. 1 , p. $284,2016$.

[132] L. Nogueira, M. Cornillet, M. Singwe-Ngandeu et al., "In Black Africans with rheumatoid arthritis, ACPA recognize citrullinated fibrinogen and the derived peptides $\alpha 36$ ${ }_{50 \mathrm{Cit}_{38,42}}$ and $\beta 60-74 \mathrm{Cit}_{60,72,74}$, like in Caucasians," Clinical Immunology, vol. 152, no. 1-2, pp. 58-64, 2014.

[133] M. Sebbag, N. Moinard, I. Auger et al., "Epitopes of human fibrin recognized by the rheumatoid arthritis-specific autoantibodies to citrullinated proteins," European Journal of Immunology, vol. 36, no. 8, pp. 2250-2263, 2006.

[134] A. Kinloch, V. Tatzer, R. Wait et al., "Identification of citrullinated $\alpha$-enolase as a candidate autoantigen in rheumatoid arthritis," Arthritis Research \& Therapy, vol. 7, no. 6, article R1421, 2005.

[135] K. L. Hyrich, K. D. Watson, A. J. Silman, D. P. M. Symmons, and The BSR Biologics Register, "Predictors of response to anti-TNF- $\alpha$ therapy among patients with rheumatoid arthritis: results from the British Society for Rheumatology Biologics Register," Rheumatology, vol. 45, no. 12, pp. 15581565, 2006.

[136] J. Hendrikx, W. Kievit, J. Fransen, and P. L. C. M. van Riel, "The influence of patient perceptions of disease on medication intensification in daily practice," Rheumatology, vol. 55, no. 11, pp. 1938-1945, 2016.

[137] F. Atzeni, P. Sarzi-Puttini, D. D. Acqua et al., "Adalimumab clinical efficacy is associated with rheumatoid factor and anti-cyclic citrullinated peptide antibody titer reduction: a one-year prospective study," Arthritis Research \& Therapy, vol. 8, no. 1, article R3, 2006.

[138] T. Lequerre, F. Jouen, M. Brazier et al., "Autoantibodies, metalloproteinases and bone markers in rheumatoid arthritis patients are unable to predict their responses to infliximab," Rheumatology, vol. 46, no. 3, pp. 446-453, 2007.

[139] F. Atzeni, M. Antivalle, F. B. Pallavicini et al., "Predicting response to anti-TNF treatment in rheumatoid arthritis patients," Autoimmunity Reviews, vol. 8, no. 5, pp. 431437, 2009.

[140] L. Mancarella, F. Bobbio-Pallavicini, F. Ceccarelli et al., "Good clinical response, remission, and predictors of remission in rheumatoid arthritis patients treated with tumor necrosis factor-alpha blockers: the GISEA study," The Journal of Rheumatology, vol. 34, no. 8, pp. 1670-1673, 2007.

[141] N. Dashti, Z. Javadi, F. Safari, S. Farahvash, and M. Zarebavani, "Estimation of diagnostic markers in rheumatoid arthritis and ankylosing spondylitis," Clinical Laboratory, vol. 63, no. 4, pp. 797-800, 2017.

[142] P. Y. Chang, C. T. Yang, C. H. Cheng, and K. H. Yu, "Diagnostic performance of anti-cyclic citrullinated peptide and rheumatoid factor in patients with rheumatoid arthritis," International Journal of Rheumatic Diseases, vol. 19, no. 9, pp. 880-886, 2016.

[143] T. Hayashi, I. Matsumoto, Y. Muraki et al., "Clinical characteristics of anti-glucose-6-phosphate isomerase antibodypositive Japanese patients with rheumatoid arthritis," Modern Rheumatology, vol. 15, no. 4, pp. 258-263, 2005.

[144] Y. Nozaki, Y. Nagare, S. Hino et al., "Therapeutic strategy and significance of serum rheumatoid factor in patients with rheumatoid arthritis during infliximab treatment," Japanese
Journal of Clinical Immunology, vol. 33, no. 3, pp. 135$141,2010$.

[145] H. Yamanaka, Y. Tanaka, N. Sekiguchi et al., "Retrospective clinical study on the notable efficacy and related factors of infliximab therapy in a rheumatoid arthritis management group in Japan (RECONFIRM)," Modern Rheumatology, vol. 17, no. 1, pp. 28-32, 2007.

[146] M. Cuchacovich, D. Catalan, E. Wainstein et al., "Basal anticyclic citrullinated peptide (anti-CCP) antibody levels and a decrease in anti-CCP titres are associated with clinical response to adalimumab in rheumatoid arthritis," Clinical and Experimental Rheumatology, vol. 26, no. 6, pp. 1067-1073, 2008.

[147] I. Matsumoto, D. M. Lee, R. Goldbach-Mansky et al., "Low prevalence of antibodies to glucose-6-phosphate isomerase in patients with rheumatoid arthritis and a spectrum of other chronic autoimmune disorders," Arthritis \& Rheumatism, vol. 48, no. 4, pp. 944-954, 2003.

[148] G. J. Challener, J. D. Jones, A. J. Pelzek et al., “Anti-carbamylated protein antibody levels correlate with anti-Sa (citrullinated vimentin) antibody levels in rheumatoid arthritis," The Journal of Rheumatology, vol. 43, no. 2, pp. 273-281, 2016.

[149] X. Yang, M. Wang, Z. Xu et al., "Diagnostic accuracy of antiRA33 antibody for rheumatoid arthritis: systematic review and meta-analysis," Clinical and Experimental Rheumatology, vol. 34, no. 3, pp. 539-547, 2016.

[150] H. El-Banna and A. Jiman-Fatani, "Anti-cyclic citrullinated peptide antibodies and paraoxonase-1 polymorphism in rheumatoid arthritis," BMC Musculoskeletal Disorders, vol. 15, p. 379, 2014.

[151] Z. W. Dai, Z. H. Wang, Y. Y. Dong et al., "Diagnostic value of anti-citrullinated fibrinogen antibody in rheumatoid arthritis: a meta-analysis," International Journal of Rheumatic Diseases, vol. 22, no. 4, pp. 599-607, 2019.

[152] D. Manivelavan and C. K. Vijayasamundeeswari, “Anti-cyclic citrullinated peptide antibody: an early diagnostic and prognostic biomarker of rheumatoid arthritis," Journal of Clinical and Diagnostic Research, vol. 6, no. 8, pp. 1393-1396, 2012.

[153] Y. Zhao, X. Tian, and Z. Li, "Prevalence and clinical significance of antibodies to citrullinated fibrinogen (ACF) in Chinese patients with rheumatoid arthritis," Clinical Rheumatology, vol. 26, no. 9, pp. 1505-1512, 2007.

[154] H. Amital and Y. Shoenfeld, "Natural autoantibodies, heralding, protecting and inducing autoimmunity," in Autoantibodies (Second Edition), pp. 7-12, Elsevier Science, Amsterdam, Netherlands, 2007.

[155] H. U. Lutz, C. J. Binder, and S. Kaveri, "Naturally occurring auto-antibodies in homeostasis and disease," Trends in Immunology, vol. 30, no. 1, pp. 43-51, 2009.

[156] S. Avrameas, "Natural autoantibodies: from 'horror autotoxicus' to 'gnothi seauton," Immunology Today, vol. 12, no. 5, pp. 154-159, 1991.

[157] Y. Wu, S. Sukumar, M. E. El Shikh, A. M. Best, A. K. Szakal, and J. G. Tew, "Immune complex-bearing follicular dendritic cells deliver a late antigenic signal that promotes somatic hypermutation," The Journal of Immunology, vol. 180, no. 1, pp. 281-290, 2008.

[158] F. Vu, U. Dianzani, C. F. Ware, T. Mak, and J. L. Gommerman, "ICOS, CD40, and lymphotoxin $\beta$ receptors signal sequentially and interdependently to initiate a germinal center reaction," The Journal of Immunology, vol. 180, no. 4, pp. 2284-2293, 2008. 
[159] C. Louis, D. Ngo, D. B. D'Silva et al., “Therapeutic effects of a TANK-binding kinase 1 inhibitor in germinal centerdriven collagen-induced arthritis," Arthritis \& Rheumatology, vol. 71, no. 1, pp. 50-62, 2019.

[160] C. G. Vinuesa, S. G. Tangye, B. Moser, and C. R. Mackay, "Follicular B helper T cells in antibody responses and autoimmunity," Nature Reviews Immunology, vol. 5, no. 11, pp. 853865, 2005.

[161] C. G. Vinuesa, I. Sanz, and M. C. Cook, "Dysregulation of germinal centres in autoimmune disease," Nature Reviews Immunology, vol. 9, no. 12, pp. 845-857, 2009.

[162] C. G. Vinuesa, M. C. Cook, C. Angelucci et al., "A RINGtype ubiquitin ligase family member required to repress follicular helper T cells and autoimmunity," Nature, vol. 435, no. 7041, pp. 452-458, 2005.

[163] A. E. Schroder, A. Greiner, C. Seyfert, and C. Berek, "Differentiation of B cells in the nonlymphoid tissue of the synovial membrane of patients with rheumatoid arthritis," Proceedings of the National Academy of Sciences of the United States of America, vol. 93, no. 1, pp. 221-225, 1996.

[164] S. Takemura, A. Braun, C. Crowson et al., "Lymphoid neogenesis in rheumatoid synovitis," The Journal of Immunology, vol. 167, no. 2, pp. 1072-1080, 2001.

[165] T. Cantaert, J. Kolln, T. Timmer et al., "B lymphocyte autoimmunity in rheumatoid synovitis is independent of ectopic lymphoid neogenesis," The Journal of Immunology, vol. 181, no. 1, pp. 785-794, 2008.

[166] S. Han, S. Cao, R. Bheekha-Escura, and B. Zheng, "Germinal center reaction in the joints of mice with collagen-induced arthritis: An animal model of lymphocyte activation and differentiation in arthritic joints," Arthritis and Rheumatism, vol. 44, no. 6, pp. 1438-1443, 2001.

[167] C. J. Del Nagro, R. V. Kolla, and R. C. Rickert, “A critical role for complement C3d and the B cell coreceptor (CD19/CD21) complex in the initiation of inflammatory arthritis," The Journal of Immunology, vol. 175, no. 8, pp. 5379-5389, 2005.

[168] A. Dahdah, K. Habir, K. S. Nandakumar et al., "Germinal center B cells are essential for collagen-induced arthritis," Arthritis \& Rhematology, vol. 70, no. 2, pp. 193-203, 2018.

[169] A. Steiman-Shimony, H. Edelman, A. Hutzler et al., "Lineage tree analysis of immunoglobulin variable-region gene mutations in autoimmune diseases: chronic activation, normal selection," Cellular Immunology, vol. 244, no. 2, pp. 130136, 2006.

[170] M. M. Souto-Carneiro, V. Krenn, R. Hermann, A. König, and H. K. Müller-Hermelink, "IgVH genes from different anatomical regions, with different histopathological patterns, of a rheumatoid arthritis patient suggest cyclic re-entry of mature synovial B-cells in the hypermutation process," Arthritis Research, vol. 2, no. 4, p. 303, 2000.

[171] D. Cao, H. Ia Khmaladze, E. Jia et al., "Pathogenic autoreactive B cells are not negatively selected toward matrix protein collagen II," The Journal of Immunology, vol. 187, no. 9, pp. 4451-4458, 2011.

[172] M. Förster, B. Raposo, D. Ekman et al., "Genetic control of antibody production during collagen-induced arthritis development in heterogeneous stock mice," Arthritis \& Rheumatism, vol. 64, no. 11, pp. 3594-3603, 2012.

[173] K. S. Nandakumar, A. K. Lindqvist, and R. Holmdahl, “A dominant suppressive MHC class II haplotype interacting with autosomal genes controls autoantibody production and chronicity of arthritis," Annals of the Rheumatic Diseases, vol. 70, no. 9, pp. 1664-1670, 2011.

[174] B. Raposo, D. Dobritzsch, C. Ge et al., "Epitope-specific antibody response is controlled by immunoglobulin $\mathrm{V}_{\mathrm{H}}$ polymorphisms," The Journal of Experimental Medicine, vol. 211, no. 3, pp. 405-411, 2014.

[175] R. J. Ludwig, K. Vanhoorelbeke, F. Leypoldt et al., "Mechanisms of autoantibody-induced pathology," Frontiers in Immunology, vol. 8, p. 603, 2017.

[176] F. Martin and A. C. Chan, "B cell immunobiology in disease: evolving concepts from the clinic," Annual Review of Immunology, vol. 24, no. 1, pp. 467-496, 2006.

[177] P. H. Wooley, H. S. Luthra, S. K. Singh, A. R. Huse, J. M. Stuart, and C. S. David, "Passive transfer of arthritis to mice by injection of human anti-type II collagen antibody," Mayo Clinic Proceedings, vol. 59, no. 11-12, pp. 737-743, 1984.

[178] S. B. Petkova, K. N. Konstantinov, T. J. Sproule, B. L. Lyons, M. A. Awwami, and D. C. Roopenian, "Human antibodies induce arthritis in mice deficient in the low-affinity inhibitory IgG receptor Fc $\gamma$ RIIB," The Journal of Experimental Medicine, vol. 203, no. 2, pp. 275-280, 2006.

[179] K. S. Nandakumar, "Targeting IgG in arthritis: disease pathways and therapeutic avenues," International Journal of Molecular Sciences, vol. 19, no. 3, p. 677, 2018.

[180] K. S. Nandakumar and R. Holmdahl, "Therapeutic cleavage of IgG: new avenues for treating inflammation," Trends in Immunology, vol. 29, no. 4, pp. 173-178, 2008.

[181] S. F. Amirahmadi, S. Whittingham, D. E. Crombie et al., "Arthritogenic anti-type II collagen antibodies are pathogenic for cartilage-derived chondrocytes independent of inflammatory cells," Arthritis \& Rheumatism, vol. 52, no. 6, pp. 1897-1906, 2005.

[182] R. E. Gray, N. Seng, I. R. Mackay, and M. J. Rowley, "Measurement of antibodies to collagen II by inhibition of collagen fibril formation in vitro," Journal of Immunological Methods, vol. 285, no. 1, pp. 55-61, 2004.

[183] D. B. Bas, J. Su, K. Sandor et al., "Collagen antibody-induced arthritis evokes persistent pain with spinal glial involvement and transient prostaglandin dependency," Arthritis \& Rheumatism, vol. 64, no. 12, pp. 3886-3896, 2012.

[184] A. B. Farinotti, G. Wigerblad, D. Nascimento et al., "Cartilage-binding antibodies induce pain through immune complex-mediated activation of neurons," The Journal of Experimental Medicine, vol. 216, no. 8, pp. 1904-1924, 2019.

[185] O.-O. Olumuyiwa-Akeredolu, M. J. Page, P. Soma, and E. Pretorius, "Platelets: emerging facilitators of cellular crosstalk in rheumatoid arthritis," Nature Reviews Rheumatology, vol. 15, no. 4, pp. 237-248, 2019.

[186] A. Krishnamurthy, V. Joshua, A. H. Hensvold et al., "Identification of a novel chemokine-dependent molecular mechanism underlying rheumatoid arthritis-associated autoantibodymediated bone loss," Annals of the Rheumatic Diseases, vol. 75, no. 4, pp. 721-729, 2016.

[187] A. Krishnamurthy, A. J. Ytterberg, M. Sun et al., "Citrullination controls dendritic cell transdifferentiation into osteoclasts," The Journal of Immunology, vol. 202, no. 11, pp. 3143-3150, 2019.

[188] G. Wigerblad, D. B. Bas, C. Fernades-Cerqueira et al., "Autoantibodies to citrullinated proteins may induce joint pain independent of inflammation," Annals of the Rheumatic Diseases, vol. 75, no. 4, pp. 730-738, 2016. 
[189] L. A. Trouw, E. M. Haisma, E. W. N. Levarht et al., "Anticyclic citrullinated peptide antibodies from rheumatoid arthritis patients activate complement via both the classical and alternative pathways," Arthritis \& Rheumatism, vol. 60, no. 7, pp. 1923-1931, 2009.

[190] K. L. L. Habets, L. A. Trouw, E. W. N. Levarht et al., "Anticitrullinated protein antibodies contribute to platelet activation in rheumatoid arthritis," Arthritis Research \& Therapy, vol. 17, no. 1, p. 209, 2015.

[191] V. P. K. Nell, "Autoantibody profiling as early diagnostic and prognostic tool for rheumatoid arthritis," Annals of the Rheumatic Diseases, vol. 64, no. 12, pp. 1731-1736, 2005.

[192] C. Rommel, M. Camps, and H. Ji, "PI3K $\delta$ and PI $3 \mathrm{~K} \gamma$ : partners in crime in inflammation in rheumatoid arthritis and beyond?," Nature Reviews Immunology, vol. 7, no. 3, pp. 191-201, 2007.

[193] A. Mastrangelo, T. Colasanti, C. Barbati et al., "The role of posttranslational protein modifications in rheumatological diseases: focus on rheumatoid arthritis," Journal of Immunology Research, vol. 2015, Article ID 712490, 10 pages, 2015.

[194] G. Vidarsson, G. Dekkers, and T. Rispens, "IgG subclasses and allotypes: from structure to effector functions," Frontiers in Immunology, vol. 5, p. 520, 2014.

[195] R. Abès and J. L. Teillaud, "Impact of glycosylation on effector functions of therapeutic IgG," Pharmaceuticals, vol. 3, no. 1, pp. 146-157, 2010.

[196] R. M. Anthony, F. Wermeling, and J. V. Ravetch, "Novel roles for the IgG Fc glycan," Annals of the New York Academy of Sciences, vol. 1253, pp. 170-180, 2012.

[197] J. N. Arnold, M. R. Wormald, R. B. Sim, P. M. Rudd, and R. A. Dwek, "The impact of glycosylation on the biological function and structure of human immunoglobulins," Annual Review of Immunology, vol. 25, no. 1, pp. 21-50, 2007.

[198] D. Zhu, H. McCarthy, C. H. Ottensmeier, P. Johnson, T. J. Hamblin, and F. K. Stevenson, "Acquisition of potential $\mathrm{N}$-glycosylation sites in the immunoglobulin variable region by somatic mutation is a distinctive feature of follicular lymphoma," Blood, vol. 99, no. 7, pp. 2562-2568, 2002.

[199] S. Bournazos and J. V. Ravetch, "Diversification of IgG effector functions," International Immunology, vol. 29, no. 7, pp. 303-310, 2017.

[200] X. Wang, M. Mathieu, and R. J. Brezski, "IgG Fc engineering to modulate antibody effector functions," Protein \& Cell, vol. 9, no. 1, pp. 63-73, 2018.

[201] A. Bondt, M. H. J. Selman, A. M. Deelder et al., "Association between galactosylation of immunoglobulin $\mathrm{G}$ and improvement of rheumatoid arthritis during pregnancy is independent of sialylation," Journal of Proteome Research, vol. 12, no. 10, pp. 4522-4531, 2013.

[202] M. Flögel, G. Lauc, I. Gornik, and B. Maček, "Fucosylation and galactosylation of IgG heavy chains differ between acute and remission phases of juvenile chronic arthritis," Clinical Chemistry and Laboratory Medicine, vol. 36, no. 2, pp. 99102, 1998.

[203] A. Matsumoto, K. Shikata, F. Takeuchi, N. Kojima, and T. Mizuochi, "Autoantibody activity of IgG rheumatoid factor increases with decreasing levels of galactosylation and sialylation," Journal of Biochemistry, vol. 128, no. 4, pp. 621-628, 2000.
[204] R. B. Parekh, R. A. Dwek, B. J. Sutton et al., "Association of rheumatoid arthritis and primary osteoarthritis with changes in the glycosylation pattern of total serum IgG," Nature, vol. 316, no. 6027, pp. 452-457, 1985.

[205] Y. Rombouts, E. Ewing, L. A. van de Stadt et al., "Anticitrullinated protein antibodies acquire a pro-inflammatory Fc glycosylation phenotype prior to the onset of rheumatoid arthritis," Annals of the Rheumatic Diseases, vol. 74, no. 1, pp. 234-241, 2015.

[206] M. Tomana, R. E. Schrohenloher, W. J. Koopman, G. S. Alarcän, and W. A. Paul, "Abnormal glycosylation of serum IgG from patients with chronic inflammatory diseases," Arthritis \& Rheumatism, vol. 31, no. 3, pp. 333-338, 1988.

[207] Y. Kaneko, F. Nimmerjahn, and J. V. Ravetch, "Antiinflammatory activity of immunoglobulin G resulting from Fc sialylation," Science, vol. 313, no. 5787, pp. 670-673, 2006.

[208] J. S. Axford, "Glycosylation and rheumatic disease," Biochimica et Biophysica Acta (BBA) - Molecular Basis of Disease, vol. 1455, no. 2-3, pp. 219-229, 1999.

[209] A. Ercan, J. Cui, D. E. Chatterton et al., "Aberrant IgG galactosylation precedes disease onset, correlates with disease activity, and is prevalent in autoantibodies in rheumatoid arthritis," Arthritis and Rheumatism, vol. 62, no. 8, pp. 2239-2248, 2010.

[210] R. Malhotra, M. R. Wormald, P. M. Rudd, P. B. Fischer, R. A. Dwek, and R. B. Sim, "Glycosylation changes of IgG associated with rheumatooid arthritis can activate complement via the mannose-binding protein," Nature Medicine, vol. 1, no. 3, pp. 237-243, 1995.

[211] A. Sebastian, M. A. Alzain, C. O. Asweto et al., "Glycan biomarkers for rheumatoid arthritis and its remission status in Han Chinese patients," OMICS: A Journal of Integrative Biology, vol. 20, no. 6, pp. 343-351, 2016.

[212] F. E. van de Geijn, M. Wuhrer, M. H. J. Selman et al., "Immunoglobulin G galactosylation and sialylation are associated with pregnancy-induced improvement of rheumatoid arthritis and the postpartum flare: results from a large prospective cohort study," Arthritis Research \& Therapy, vol. 11, no. 6, article R193, 2009.

[213] C. Schwedler, T. Häupl, U. Kalus et al., "Hypogalactosylation of immunoglobulin $\mathrm{G}$ in rheumatoid arthritis: relationship to HLA-DRB1 shared epitope, anticitrullinated protein antibodies, rheumatoid factor, and correlation with inflammatory activity," Arthritis Research \& Therapy, vol. 20, no. 1, p. 44, 2018.

[214] D. Sun, F. Hu, H. Gao et al., "Distribution of abnormal IgG glycosylation patterns from rheumatoid arthritis and osteoarthritis patients by MALDI-TOF-MS ${ }^{n}$," The Analyst, vol. 144, no. 6, pp. 2042-2051, 2019.

[215] Y. Kuroda, M. Nakata, S. Hirose et al., "Abnormal IgG galactosylation in MRL-lpr/lpr mice: pathogenic role in the development of arthritis," Pathology International, vol. 51, no. 12, pp. 909-915, 2001

[216] N. Tsuchiya, T. Endo, K. Matsuta et al., "Effects of galactose depletion from oligosaccharide chains on immunological activities of human IgG," The Journal of Rheumatology, vol. 16, no. 3, pp. 285-290, 1989.

[217] P. Garred, H. O. Madsen, H. Marquart et al., "Two edged role of mannose binding lectin in rheumatoid arthritis: a cross sectional study," The Journal of Rheumatology, vol. 27, no. 1, pp. 26-34, 2000. 
[218] E. Gińdzieńska-Sieśkiewicz, I. Radziejewska, I. Domysławska et al., "Changes of glycosylation of IgG in rheumatoid arthritis patients treated with methotrexate," Advances in Medical Sciences, vol. 61, no. 2, pp. 193-197, 2016.

[219] M. Pasek, M. Duk, M. Podbielska et al., "Galactosylation of IgG from rheumatoid arthritis (RA) patients - changes during therapy," Glycoconjugate Journal, vol. 23, no. 7-8, pp. 463-471, 2006.

[220] T. W. Rademacher, P. Williams, and R. A. Dwek, "Agalactosyl glycoforms of IgG autoantibodies are pathogenic," Proceedings of the National Academy of Sciences of the United States of America, vol. 91, no. 13, pp. 6123-6127, 1994.

[221] F. S. van de Bovenkamp, L. Hafkenscheid, T. Rispens, and Y. Rombouts, "The emerging importance of IgG Fab glycosylation in immunity," Journal of Immunology, vol. 196, no. 4, pp. 1435-1441, 2016.

[222] A. Youings, S. C. Chang, R. A. Dwek, and I. G. Scragg, "Sitespecific glycosylation of human immunoglobulin $\mathrm{G}$ is altered in four rheumatoid arthritis patients," Biochemical Journal, vol. 314, no. 2, pp. 621-630, 1996.

[223] Y. Ohmi, W. Ise, A. Harazono et al., "Sialylation converts arthritogenic IgG into inhibitors of collagen-induced arthritis," Nature Communications, vol. 7, no. 1, article 11205, 2016.

[224] R. M. Anthony, F. Nimmerjahn, D. J. Ashline, V. N. Reinhold, J. C. Paulson, and J. V. Ravetch, "Recapitulation of IVIG anti-inflammatory activity with a recombinant IgG Fc," Science, vol. 320, no. 5874, pp. 373-376, 2008.

[225] S. L. Lundström, C. Fernandes-Cerqueira, A. J. Ytterberg et al., "IgG antibodies to cyclic citrullinated peptides exhibit profiles specific in terms of IgG subclasses, Fc-glycans and a fab-Peptide sequence," PLoS One, vol. 9, no. 11, article e113924, 2014.

[226] U. Harre, S. C. Lang, R. Pfeifle et al., "Glycosylation of immunoglobulin G determines osteoclast differentiation and bone loss," Nature Communications, vol. 6, no. 1, article 6651, 2015.

[227] Y. Rombouts, A. Willemze, J. J. B. C. van Beers et al., "Extensive glycosylation of ACPA-IgG variable domains modulates binding to citrullinated antigens in rheumatoid arthritis," Annals of the Rheumatic Diseases, vol. 75, no. 3, pp. 578-585, 2016.

[228] M. Collin and A. Olsén, "Effect of SpeB and EndoS from Streptococcus pyogenes on human immunoglobulins," Infection and Immunity, vol. 69, no. 11, pp. 7187-7189, 2001.

[229] M. Collin and A. Olsén, "EndoS, a novel secreted protein from Streptococcus pyogenes with endoglycosidase activity on human IgG," The EMBO Journal, vol. 20, no. 12, pp. 3046-3055, 2001.

[230] M. Allhorn, A. I. Olin, F. Nimmerjahn, and M. Collin, "Human IgG/Fc $\gamma$ R interactions are modulated by streptococcal IgG glycan hydrolysis," PLoS One, vol. 3, no. 1, article e1413, 2008.

[231] K. S. Nandakumar, M. Collin, A. Olsén et al., "Endoglycosidase treatment abrogates IgG arthritogenicity: importance of IgG glycosylation in arthritis," European Journal of Immunology, vol. 37, no. 10, pp. 2973-2982, 2007.

[232] K. S. Nandakumar, M. Collin, K. E. Happonen et al., "Streptococcal endo- $\beta$ - $N$-acetylglucosaminidase suppresses antibodymediated inflammation in vivo," Frontiers in Immunology, vol. 9, p. 1623, 2018. 


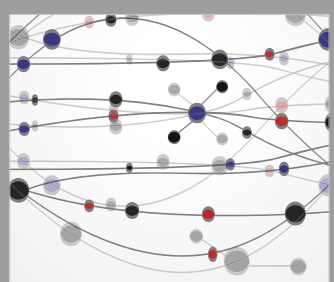

The Scientific World Journal
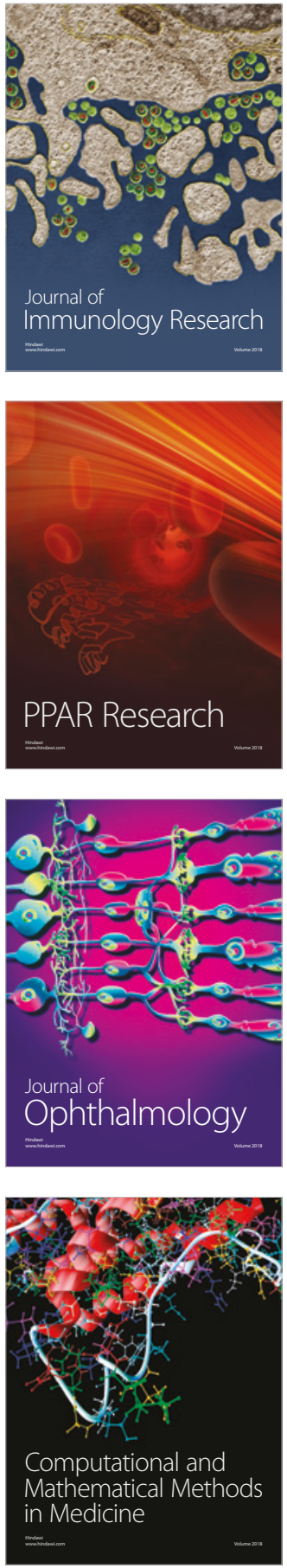

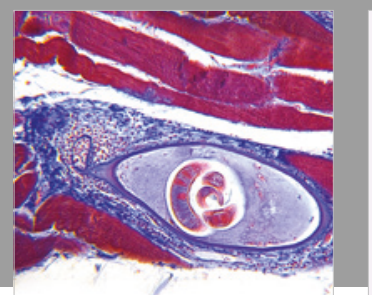

Gastroenterology Research and Practice

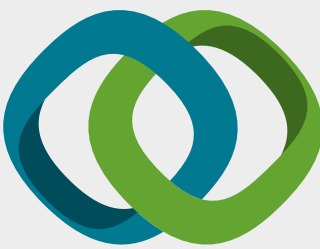

\section{Hindawi}

Submit your manuscripts at

www.hindawi.com
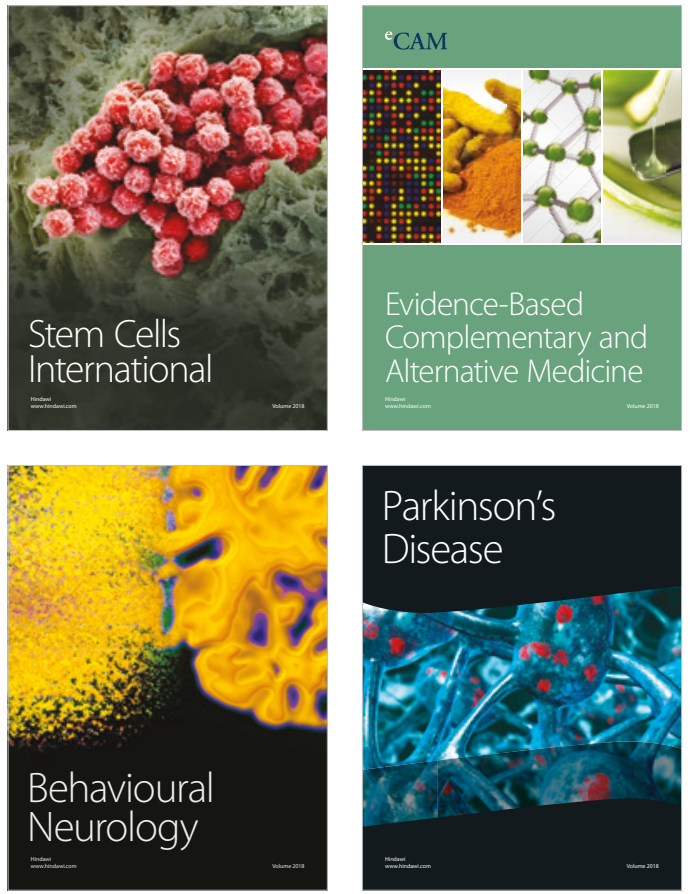

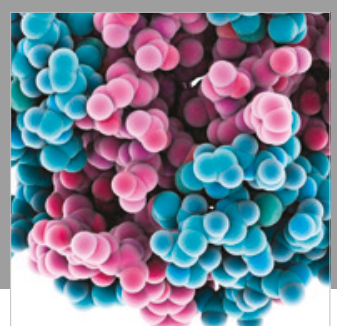

ournal of

Diabetes Research

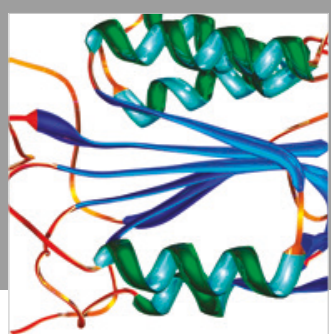

Disease Markers
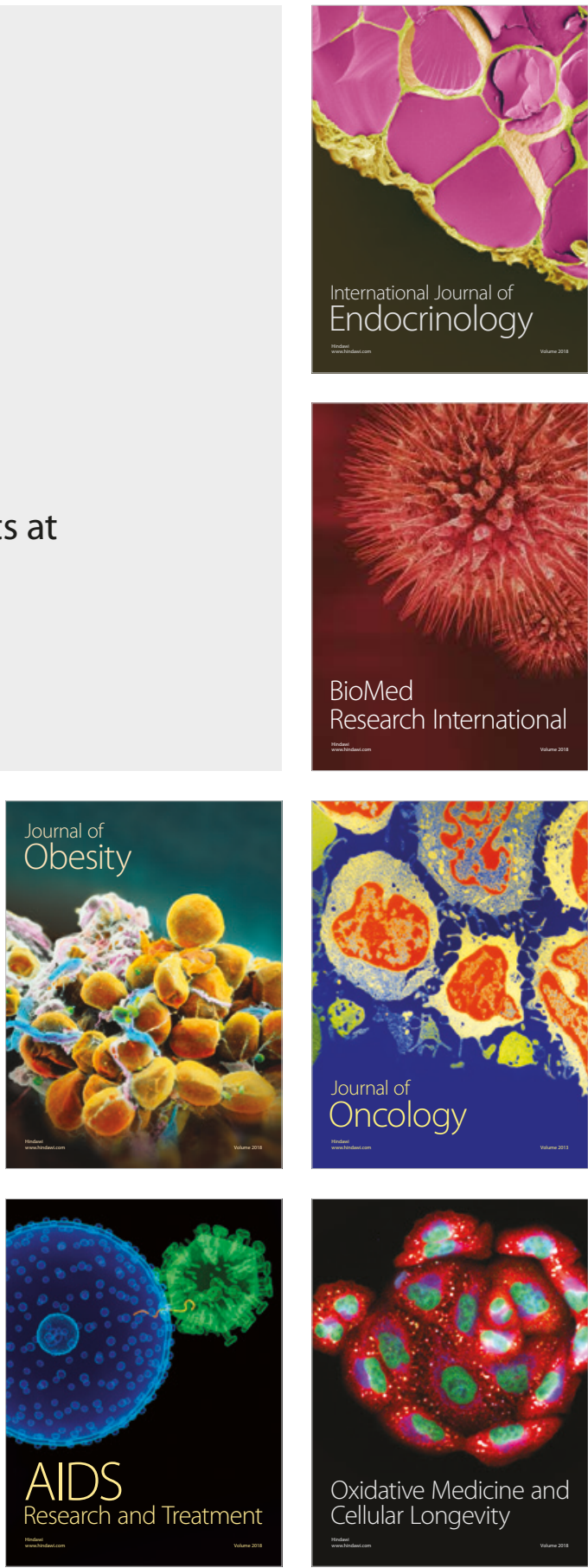